\title{
İnönü Muharebeleri Sırasında Hilal-i Ahmer ve Yunan Salib-i Ahmer Cemiyetlerinin Çalışmalarının Analitik Bir Yaklaşımla Ele Alınması ${ }^{1}$
}

Fahri ÖZTEKE ${ }^{2}$

\author{
Başvuru Tarihi: 04.01.2021 \\ Kabul Tarihi: 23.02 .2021 \\ Makale Türü: Araştırma Makalesi
}

\section{Öz}

Son yıllarda Millî Mücadele (1918-1923) üzerine yapılmış çalışmalarda belirgin bir artı̧s olsa da böylesi kritik bir savaşta, sağlık hizmetlerinin hangi koşullarda yürütüldüğüyle ilgili araştırmaların henüz yeterli olduğunu söylemek mümkün değildir. Bu çalışmada milli güçler, Batı Anadolu'daki işgaller ve İnönü Muharebeleri sırasında düşman kuvvetleriyle çarpışırken nasıl bir sağlık organizasyonu meydana getirildiği ele alınmıştır. Söz konusu organizasyonda, Hilal-i Ahmer Cemiyetinin konumu somut verilere dayandırlarak irdelenmiştir. Bugün Türk Kızılayı olarak bilinen cemiyetin, uluslararası savaş hukuku ve insani ölçütleri referans kabul ederek hem Türkler hem de Yunanlılara ulaştırdığı hizmetler hakkında bilgi verilmiştir. Sağlıkla birlikte başka alanlarda da önemli işlevler yerine getirdiği orijinal kaynaklar bazında göz önüne serilmiştir. Türk tarafındaki bu gelişmelere karşılık, Yunan Salib-i Ahmer Cemiyetinin nasıl bir pozisyon takındı̆̆ kritize edilmişsir. Bu kapsamda cemiyetin bazı zamanlar tıbbi misyonerlik çalışmaları yürüttüğ̈̈ bazı zamanlar da taraflar arasındaki gerilimi tırmandıracak etkinliklerde bulunduğu belirtilmiştir. Bizans ve Pontus Rum İmparatorluklarını yeniden kurma düşüncesine hizmet edip açtığı hastaneleri silah deposuna çeviren Salib-i Ahmerin, Anadolu'daki görünümünün bir sağlık kuruluşu olmaktan çok daha öteye geçtiği tezi desteklenmiştir. Siyasi ve askeri olaylardaki rollerinin yanı sıra her iki cemiyetin oluşturduğu sosyolojik imgenin değerlendirilmesi yapılmıştır.

Anahtar Kelimeler: Sosyal Dayanışma, Sağlık Hizmetleri, Silah Nakli, Megali İdea, Millî Mücadele ve Cumhuriyet Tarihi

Atıf: Özteke, F. (2021). İnönü Muharebeleri sırasında Hilal-i Ahmer ve Yunan Salib-i Ahmer cemiyetlerinin çalışmalarının analitik bir yaklaşımla ele alınması. Anadolu Üniversitesi Sosyal Bilimler Dergisi, 21(Özel Sayı), 59-86.

\footnotetext{
${ }^{1}$ Bu çalışma etik kurul izin belgesi gerektirmemektedir.

${ }^{2}$ Batman Üniversitesi Fen Edebiyat Fakültesi Tarih Bölümü, fozteke26@gmail.com, ORCID: 0000000265822089
} 


\title{
Examining the Activities of Hilal-i Ahmer and Greek Salib-i Ahmer Communities During the Battles of İnönü with an Analytical
} Approach

\author{
Fahri ÖZTEKE ${ }^{3}$
}

Submitted by: 04.01 .2021

Accepted by: 23.02.2021

Article Type: Research Article

\begin{abstract}
Although there has been a significant increase in the studies on the National Struggle (1918-1923) in recent years, it is not possible to say that the researches about the conditions under which health services are carried out in such a critical war are still sufficient. In this study, what kind of a health organization was formed while the national forces were fighting with the enemy forces during the invasions in Western Anatolia and the Battles of Inönü was discussed. In the said organization, the position of the Hilal-i Ahmer Community was examined on the basis of concrete data. Information was given about the services that the community, known as the Turkish Red Crescent (Türk Kizllayl) today, provides to both Turks and Greeks, taking international laws of war and humanitarian criteria as a reference. It has been demonstrated on the basis of original sources that it fulfills important functions in other fields besides health. In response to these developments on the Turkish side, the position of the Greek Salib-i Ahmer Community has been criticized. In this context, it was stated that the community sometimes carried out medical missionary activities and at other times carried out activities that would escalate the tension between the parties. Salib-i Ahmers, who served the idea of rebuilding the Byzantine and Pontus Greek Empires and turned their hospitals into a weapon depot, was supported by the thesis that his appearance in Anatolia went beyond being a health institution. Besides their roles in political and military events, the sociological image formed by both communities was evaluated.
\end{abstract}

Keywords: Social Solidarity, Health Service, Weapon Transport, Megali Idea, National Struggle and History of the Republic

\footnotetext{
${ }^{3}$ Batman University Faculty of Arts and Sciences Department of History, fozteke26@gmail.com, ORCID: 0000000265822089
} 


\section{Giriş}

Türkiye, Sanayi Devriminden sonra verimli toprakları ve zengin ekonomik kaynaklarıyla emperyalist devletlerin zihninde ciddi yer edinmiştir. Bu topraklarda 600 yılı aşkın bir süredir varlığını sürdürmüş Osmanlı Devleti ise, 20.yüzyıla gelindiğinde art arda yaşadığı travmalar sonunda artık miadını tamamlamıştır. Balkan ve Birinci Dünya Savaşları’nın kaybedilmesiyle “Şark Meselesi” (Karadağ, 2005, s. 21) olarak adlandırılan plan, Batılı devletlerce daha büyük bir iştahla devreye konmuştur. Anadolu’da Türk varlığının tartışılmaya başlandığı bu evrede imzalan Mondros Mütarekesi ve Sevr Antlaşması “Megali İdea” ülküsündeki Yunanlıları da harekete geçirmiştir (Akşin, 2017, s. 287). Üstüne üstlük İngiltere ve Fransa, İtalya'nın Akdeniz’e yönelik hedeflerini engellemek için Yunanistan'ı açıktan ya da üstü örtülü şekilde desteklemişlerdir. Bu koşullarda olaylar istediği seyirde gelişen Yunan Ordusu, bir oldubittiyle 15 Mayıs 1919 günü İzmir'i işgal etmiştir. Akabinde de Batı Ege'de birçok yeri ele geçirmişlerdir. Bu sırada Türk tarafında Ethem isyanıyla patlak veren iç savaş, Yunanlıların ekmeğine yağ sürmüş ve 1921 yllı başlarında Bursa-Uşak hattından Afyon-İnönü istikametine doğru ilerlemişlerdir (Turan, 1996, s. 746).

Her yönüyle "Millî” nitelikteki Türk birlikleriyle, "gayri milli” bir hüviyete sahip olup emperyalistlerin aparatı konumundaki Yunan güçleri, 9 Ocak 1921'de İnönü civarında karşılaşmışlardır (Erdeha, 1975, s. 33). İki taraf askerî açıdan kıyaslandığında Yunan Ordusu, Türk kuvvetlerinin neredeyse yaklaşık üç katı idi (Genelkurmay Başkanlığı, 1995). Batı Cephesi Komutanı Albay İsmet Bey, Birinci İnönü Muharebesi (6-10 Ocak 1921)'ni ilk zamanlar Kütahya'dan yönetmiştir. Ancak Yunan saldırılarının şiddetlenmesi üzerine 10 Ocak sabahı trenle İnönü’ye ulaşmıştır (Genelkurmay Başkanlığı, 2000). Bu süreçte Mustafa Kemal Atatürk ise, Mecliste yaptığı konuşmalar aracılığıyla savaşın gidişatı hakkında kamuoyunu bilgilendirmiştir. Askeri strateji konusunda tüm dünyanın takdir ettiği bir lider olan Mustafa Kemal Atatürk, muharebede Yunanlıların en ufak bir zafiyetini dahi "zafer" şeklinde yansıtarak Türk Ordusu ve Millî Hükümetin psikolojik olarak güçlenmesine katkıda bulunmuştur (Selışık, 2006, s. 1). Milne Hattından çıkarak 20 gün içinde Eskişehir önlerine kadar gelen Yunan askerleri 11 Ocak sabahı geri püskürtülmüştür. Böylece TBMM’nin tesis ettiği “Düzenli Ordu” birlikleri ilk askeri zaferini kazanmıştır (Genelkurmay Askeri Tarih ve Stratejik Etüt ve Denetleme Başkanlığı Arşivi [ATASE], 7901). Bu zafer, peyderpey Sevr'den cayışların başlamasını sağlayacak ilk adımlardan biri olmuştur. Zira İtilaf Devletleri, arzu etmedikleri halde TBMM Hükümetini Londra'daki konferansa çağırmak durumunda kalmışlardır (Sofuoğlu ve Yıldırım, 2018).

Tasarılarını evrelere ayıran ve nihai hedef olarak kendilerine Ankara'daki Hükümeti ortadan kaldırmayı belirleyen İtilaflar, Londra'da Türk diplomasisinin direncini kıramayınca Yunanlıları tekrar kışkırtmışlardır. Önceki yenilginin acısını unutmayan ve Sevr’i silah zoruyla Türklere kabul ettireceğini sanan Yunanlıların taarruza kalkışmasıyla İkinci İnönü Muharebesi (23 Mart-4 Nisan 1921) başlamıştır. Her ne kadar Türk Ordusu, bu sefer savaşa daha hazırlıklı yakalansa da askeri veriler yine Yunan birliklerinin lehineydi. Bu muharebede, İsmet Bey'in ifadesiyle iki tarafta binlerce kayıp vermiştir (Selek, 2006, s. 241). Mağlup Yunanlılar, Bursa'ya kadar çekilirken bölgedeki okul ve camilerin birçoğunu yakıp yıkmışlardır. Türk milleti bu zaferle "makûs talihini” değiştirse de verilen şehit sayısı hiçte az olmamıştır (Köstüklü, 2008, s. 306, 315). Ancak yine de İkinci İnönü'de elde edilen zafer, o gün için ülkede çok gerekli olan moral birliğinin oluşmasına büyük katkı sağlamıştır. Yunanistan'da ise, İnönü Muharebeleri’nde uğranılan hezimetten sonra ülkenin para birimi Drahminde bile ciddi değer kaybı yaşanmıştır (Akşam, 1337, s. 1).

Yunanistan'ın Batı Anadolu’ya yönelik tasarıları, askeri stratejilerin ve tarihi gerçeklerin çok ötesine geçmişti. $\mathrm{Bu}$ yüzden işlerinin hayli zor olduğu bilinciyle İzmir'e girdikleri andan itibaren Anadolu'da epey kan dökmüşlerdir (Türkmen, 2016, s. 18). Çoğu yerde, Yunan ilerleyişinin “mezalim” den bir farkı kalmamıştır. Yunanlıların insanlık dışı yaklaşımları ve Türk Ordusunun kararlığı, iki taraf arasındaki çatışmalarda sağlık hizmetlerini daha da önemli hale getirmiştir. Topyekûn bir direniş hareketinin adı olan Millî Mücadele siyasi, sosyal, askeri ve ekonomik ögelerin bileşkesinden meydana gelmekteydi. Sağlık hizmetleriyse başta askeri saha 
olmak üzere söz konusu ögelerin hepsi ile bir şekilde bağlantılıydı. Yıllardır devlet otoritesinden yoksun ülkede sağlık alanındaki genel tablo içler acısı bir durumdaydı. Bu nedenle TBMM'nin ivedilikle ilk el attığ 1 konulardan biri, hasta ve yaralıların (mecruhin) tedavisini sağlamak olmuştur (Akdur, 1999, s. 49). Fakat bu sırada Osmanlıya ait Hilal-i Ahmerden de olabildiğince faydalanılmıştır. Öyle ki, temelleri 19.yüzyılın ikinci yarısında atılan Hilal-i Ahmer zaman zaman milliyetçilerle İstanbul Hükümetleri arasında köprü görevi dahi görmüştür (Akgün, 2012, s. 120). Türk tarafının öncelikle sağlık hizmetleriyle uğraşan hatta esirlere kitap dağıtacak kadar hümanist bir görünüm arz eden cemiyetine karşın (Anameriç; 2010, s. 26, 27); İngiliz destekli Yunanlılar ise, sağlık alanında işgalleri hızlandıracak "paravan" bir yapılanmaya gitmişlerdir. Öyle ki bu yapı, savaşın uzamasına tesir edip daha fazla can kaybına zemin hazırlamıştır. Yunan-Rum komitecileriyle Salib-i Ahmer mensupları çoğu yerde birlikte çalışmışlardır (Güler, 1999, s. 90).

\section{Sağlık Lojistiği ve Eskişehir Hilal-i Ahmer Hastanesi}

TBMM’nin açlmasından çok kısa bir süre sonra "Sıhhiye ve Muavenet-i İçtimaiye Vekâleti” yani bugünkü karşıllı̆ı ile "Sağlık Bakanlığı" kurulmuştur. İlk Vekilliğini Dr. Adnan Bey (Adıvar)'in yürüttüğü Vekâlet, ülkedeki bütün sivil sağlık örgütlenmesinin başı kabul edilmiştir. Bünyesinde taşra teşkilatı dışında Hıfzıssıhha Dairesi, Sicil Dairesi, Muhasebe ve Evrak Kalemi olmak üzere üç ana birim mevcuttu (Sağlık ve Sosyal Yardım Bakanlığı, 1973). Gerek düşman birliklerinin saldırıları gerekse Damat Ferit Hükümetinin tutumu, böyle bir organizasyonun oluşumunu zorunlu kılmıştı. Bu arada İngiltere'de dahi sağlık hizmetlerinin 1919'dan itibaren ayrı bir bakanlık nezdinde yürütülmeye başlandığı dikkate alınırsa, o günkü yöneticilerin ileri görüşlülügünü ve halkın sağlığına verdikleri önemi anlamak pekte zor olmasa gerekir (Dirican, 1970, s. 185). Fakat çetin savaş koşullarında tek başına TBMM'nin aldığı önlemler, yaralıların tedavisi ve bulaşıcı hastalıkların engellemesi için yeterli olmamıştır. Bunun üzerine genel merkezinin Millî Mücadele’ye karşı sıcak baktı̆̆ı Hilal-i Ahmer Cemiyeti ile koordineli hareket edilerek eksiklikler giderilmeye çalışılmıştır.

Müdafaa-i Millîye Vekâleti, Sıhhiye ve Muavenet-i İçtimaiye Vekâleti, Aşâir ve Muhâcirîn Müdüriyet-i Umûmiyesi ile Hilal-i Ahmer arasında milliyetçilerin yegâne örgütlenme odağı olan TBMM üzerinden iş birliği sağlanmıştır. Bu yolla özellikle askeri hastanelerin her türlü gereksinimi karşılama süreci kısaltılmıştır (Devlet Arşivleri Başkanlığı Cumhuriyet Arşivi [DABCA], 1921). Başta Batı Cephesi olmak üzere bağımsızlık mücadelesi verilen her bölgeye ve halk tabakalarına "yardım isteyeni asla geri çevirme" (Kur’an-1 Kerim 93: 10) prensibinden hareketle sağlı hizmetleri yetiştirilmiştir. Ortaya çıan tabloda yaralılar, göçmenler/mülteciler ve hastalar çoğu zaman çözüm noktası olarak Hilal-i Ahmeri görmüşlerdir. Bunda eski sağlık teşkilâtının personel, tıbbi malzeme ve teçhizat bakımından yetersiz kalmasının rolü büyük olmuştur.

Hilal-i Ahmer Cemiyeti işgaller sırasında yapılan eziyetler, halkın sefaleti ve kırıma yol açan hastalıklar nedeniyle Millî Mücadele yıllarında ilk olarak Doğu Anadolu ve Doğu Karadeniz bölgelerinde örgütlenmiştir. Bölge illerine İmdat Heyetleri yollayarak vatandaşların yardımına koşmuştur (Sarıhan, 1993; Devlet Arşivleri Başkanlığı Osmanlı Arşivi [DABOA], 1337). Yunan işgalini müteakip günlerde Batı Anadolu'da da sağlık heyetleri tesis edilmiştir. Bu heyetler, birçok ihtiyaç sahibine iaşe ile giyim kuşam gereksinimlerinin karşılanması konusunda yardımda bulunmuştur. Her türlü ilaç ve tıbbi malzemenin tedariki için uğraşılmıştır (Arslan, 2010, s. 228). İşgal bölgelerine yakın yerlerde dispanser ve hastaneler açllmıştır. Hilal-i Ahmer personeli adeta "mobil" şekilde çalışmışır. Bu durumda TBMM, bazı düzenlemeler yaparak onların daha rahat hareket etmesi için çeşitli olanaklar sunmuştur. Hilal-i Ahmer bünyesindeki tüm personelin askerler gibi trenlerden ücretsiz yararlanması sağlanmış ve ihtiyaç halinde sağlık malzemelerinin başka yerlere taşınması kolaylaşmıştır (DABCA, 1920). Belirtilen türden uygulamaların oluşturduğu sinerji halkın ulusal direnişe olan katılımını da arttırmıştır.

İlk işgal evresinde milli kuvvetlerin karargâhı olarak kullanılan Akhisar ve çevresinde Hilal-i Ahmer, çok önemli çalışmalara imza atmıştır (Çapa, 2006, s. 1). Dördüncü İmdadı Sıhhi Heyeti çatısı altında Akhisar'dan 
Nazilli, Çine, İzmir ve Alaşehir'e sağlık ekipleri yollanmıştır. Soma'daki göçmen hastanesinin bütün masrafları cemiyet tarafından karşılanmış ve hastanenin idaresi Akhisar Hilal-i Ahmer Cemiyetine devredilmiştir (DABCA, 1920). Balıkesir'deki aşhane aracılığıyla göçmenlere günlük yemek servisi yapılmıştır. Batı Ege'de halk sıtma ve frengiye karşı bilinçlendirilmiştir. Çine, Söke, Dinar, Koçarlı ile Burdur'da laboratuvar ve dispanserler hizmet vermiştir. Binlerce kadın, çocuk, yaşlı ve hastaya battaniye dağıtılmıştır (Bayar, 1997, s. 21). Millî Mücadele boyunca yurt çapında Hilal-i Ahmer aracilığıyla 33.172 yaralı ve hasta sağlığına kavuşturulmuştur (Hacıfettahoğlu, 2009, s. 16). Bu, günümüzde dahi tam teşekküllü sağlık donanımına sahip bir devlet için hiçte kolay üstesinden gelinecek bir rakam değildir.

Belirtilen kapsamdaki hizmetler, Yunan ordusunun 22 Haziran 1920'de Akhisar ve Balıkesir'i işgaline kadar sürdürülmüştür. İşgal sırasında Yunan askerleri, uluslararası antlaşmaları (Cenevre Mukavelenamesi ve Lahey Konferansı) hiçe sayarak Hilal-i Ahmer Heyetine karşı oldukça sert davranmıştır (Turan, 2006, s. 200, 264). Bunun üzerine heyet, tıbbi malzemeleri ve depolardaki yiyecekleri dahi toplayamadan dağlardaki yolları kullanarak Bursa üzerinden Eskişehir'e gelmiştir. Burada Hilal-i Ahmer Murahhası (delegesi) Dr. İsmail Besim Paşa'nın önderliğinde 15 Temmuz 1920 günü ilk aşamada 50 yataklı bir hastane hizmete sunulmuştur. İhtiyaca binaen Müdafaa-i Millîye Vekâletinin talimatıyla yatak kapasitesi zaman içinde 200'e kadar artırılmıştır (Çapa, 2010, s. 104). Hilal-i Ahmer Merkez-i Umumisi tarafindan cemiyetin Meclis-i Umumisine sunulan raporda, hastanenin ağır yaralıların tedavisiyle ilgilenmek dışında yeni birimleri (göz, kulak ve boğaz klinikleri) aracılığıyla diğer askeri hastanelerin yükünü de hafiflettiğine işaret edilmiştir: "15 Temmuz 336 [1920] tarihinde güşad edilen iki yüz yataklı Eskişehir hastanesi Birinci ve İkinci İnönü Muharebeleri mecruhlarını tedavi ettiği gibi görülen lüzum üzerine ayrıca göz, boğaz, kulak hastalıklarına ait ihtisas şubeleri güşad edilerek şehrin askeri hastanelerinin bu şuabata ait hastaları dahi tedavi olunmuştur” (Uluğtekin, 2013, s. 105).

İnönü Muharebeleri'nde büyük önem taşıyan hastanede, Eskişehir işgal edilene kadar 1140 yaralıya bakılmış ve bunun 531'i iyileşerek taburcu edilmesi sağlanmıştır: "19 Temmuz 337 [1921] tarihine kadar ifa-yı vazife eden bu hastanemizin “1140" mecruhu kabul ve tedavi eylediği ber-vech-i ati resmi istatistikten müsteban olur" (Uluğtekin, 2013, s. 105). Hilal-i Ahmerin Eskişehir Hastanesindeki çalışma düzeni ve işleyişi Millî Mücadele boyunca başka şehirlerde açılan hastaneler içinde örnek teşkil etmiştir: “Bundan evvel Eskişehir'de diğer bütün hastahânelerimize numûne olacak derecede mükemmelleştirilen yüz yataklı dârü’t-tedâvînin ikinci bir eşi bi't-tabi'daha küçük bir mikyâsta olmak şartıyla- el-yevm Ankara'da küşâde bulunmaktadır” (Hâkimiyeti Millîye, 1337, s. 2).

Baştabip Şemsettin Bey'in yanı sıra Dr. Seyfettin, Dr. Fahrettin ve Operatör Dr. Ali Rıza Beylerin (Anadolu'da Yeni Gün, 1337, s. 1) büyük sorumluluk üstlendiği Eskişehir'deki hastaneyi, İnönü Muharebeleri’nde başarılı kılan sadece sahip olduğu sistemsel yapısı değildi. Personelinin göstermiş olduğu özverinin de bunda büyük payı vardı (Güneş ve Yakut, 2007). Millî Mücadele boyunca Türk toplumunun haklılı̆̆ını yabancı uyruklu basın mensuplarına anlatmayı önemseyen Mustafa Kemal Atatürk’ün yakın arkadaşlarından Fransız gazeteci Madam Berthe Georges Gaulis, Batı Anadolu'daki gözlemleri sonucunda Hilal-i Ahmer çalışanlarının yaptığı fedakârlıkları "ameliyat yapan, yaralıların pansumanlarıyla uğraşan, hastalara moral veren bu gençler yorgunluklarını kısa bir uyku ile atıyorlardı” sözleriyle aktarmaktadır (Gaulis, 1981, s. 131). Hilal-i Ahmer ekipmanları, malzeme yetersizliği ve diğer olumsuzluklardan kaynaklanan noksanlıkları insanüstü gayretleri ile telafi etmişlerdir.

Modern Türk edebiyatının önemli isimlerinden Halide Edip de Eskişehir'deki hastanede bir süreliğine çalışmıştır. Halide Edip, İnönü Muharebeleri’nin ardından Ankara Murahhasının verdiği birtakım hediyelerle 1921 Mayısı'nın son günlerinde Eskişehir'e gelmiştir (Kocatürk, 1988, s. 258, 259). Buradaki hastanede, savaş yaralılarını tedavi etmek için fahriyen hastabakıcılık yapmıştır. Daha sonra Mustafa Kemal Atatürk'ün talimatıyla Batı Cephesindeki birliklere katılmıştır. Eşi Adnan Bey'le birlikte çoğu zaman Hilal-i Ahmer'in yönetim kurulunda yer alan Halide Edip, Sakarya Muharebesi ve Büyük Taarruz'da da benzer fedakârlıklarda 
bulunmuştur (Bele, 2010, s. 220-224). Ancak O, ülkenin nasıl bir süreçten geçtiği Eskişehir'deki gözlemlerinin sonucunda tam olarak anlamıştır: "Hastane yaralılarla doluydu. Ben, otuz hasta yatan en büyük koğuşa bakıyordum... Biraz hasta bakmayı bilen benden başka Mehmet Çavuş vardı ki, o iki yüz hastabakıcıya bedeldi. Kolunun biri yaralanmış ve tüfek kullanamayacak hale geldiği için, ordu onu hastaneye vermişti” (Adıvar, 2019, s. 169). Millî Mücadele'de onbaşılık rütbesine terfi eden Halide Edip, vatanın işgallerden kurtarılması çabaları sırasında Eskişehir'deki hastanenin merkez kurumlardan biri olduğunu belirtmiştir. Bunun temel nedeninin de Hilal-i Ahmer görevlilerin sıra dışı gayretlerinden kaynaklandığını söylemiştir: "Doktorların arasında dikkatimi çeken Operatör Cemil Bey’dir. İnsanı hayrete düşüren bir adamdı. Bir günde seksen üç kol, bacak kestiğini bilirim. Bununla birlikte, bir ana gibi hastalara hitap ederdi. Adeta bir evliyayı hatırlatırdı" (Adivar, 2019, s. 170).

Hilal-i Ahmer'in Hanımlar Merkezinin faaliyetleri kapsamında İnönü Muharebeleri ve akabinde Eskişehir'deki hastanede çalışan tek kadın görevli Halide Edip değildir (Tepekaya ve Kaplan, 2010). Vazife ve vatan aşkıyla "heyet-i muhtereme" arasında yer alan eğitimli ya da gönüllü kadınların sayısının onlarca olduğu ifade edilmektedir (Akgün ve Uluğtekin, 2001). Bunlardan Hemşire Zekiye ve İkinci İnönü Muharebesi sırasında yaralı askerleri tedavi etmek için cephede düşmana yakın yerlerde dahi korkusuzca görev yapmış Ulviye Hemşire, tüm Eskişehir Hilal-i Ahmer Hastanesi ekibiyle beraber Millî Mücadele’nin komuta heyeti tarafından takdir edilmiştir:

"Eskişehir Hilâl-i Ahmer Hastahânesi hey'et-i muhteremesi arasında İslâm kadınlarına numûne-i imtisâl olacak iki hemşîrenin, Râşid Paşa torunları Zekiye ve Ulviye hanımların, mesâ'îsi kemâl-i fahr ile yâd olunmaya sezâdır. Bunlardan Ulviye Hanım Şimâl Cephesi'nin ileri kıta âtına, cephenin düşmana en yakın mahallerine kadar giderek mecrûhîn ve hastagânı tedâvi için izhâr-1 hamiyet ve ibrâz-1 cesâret eylemiştir. Mûmâ-ileyhâ hanımefendiye, matba'amıza bi'z-zât tahrîren mürâca'at eden müte'addid mecrûhlar ve yüksek rütbeli kumandânlar ordu nâmına tebrîk ve teşekkür etmektedirler. Her iki hemşîrenin ve Eskişehir Hilâl-i Ahmer Hastahânesi hey'etinin hidemât-1 fedâkârânelerini takdîr ederiz" (Tercümân-1 Hakîkat, 1337, s. 1).

Yardım ekseni hayli geniş olan Hilal-i Ahmer sayesinde eğitimli ve gönüllü kişiler temin edilerek bütün sıkıntılara rağmen hastanenin personel sorunu bir şekilde çözülmüştür (Türkiye Kızllay Derneği 73 Yıllık Hayatı 1877-1949, 1950). Ancak her daim üstesinden gelinmesi gereken bir diğer meseleyse tıbbi malzeme yetersizliği olmuştur. Çünkü hastanede farklı rahatsızlıkları bulunan birçok insan tedavi edilmişti. Eskişehir Murahhası Dr. İsmail Besim Paşa'nın önceki yıllarda Hilal-i Ahmer'in İstanbul'daki Umum Merkezinden gelen ilaç ve diğer sağlık teçhizatını muhafaza ederek meydana getirdiği büyük depo, İnönü Muharebeleri sırasında adeta can simidi görevi görmüştür. Hastanenin çoğu ihtiyacı bu depodan karşılanmıştır. Bu noktada Millî Mücadele süresince Eskişehir'de, askerlerden sivil halka yapılan sağlı hizmetlerinde İstanbul'dan gelen yardımların payı görmezden gelinemeyecek kadar önemli idi (Fettahoğlu, 2009, s. 35, 36). Ayrıca Müdafaa-i Millîye Vekâletinin topladığı vergilerin büyük bir kısmını tıbbi malzeme alımında kullanması ve bunları Eskişehir'deki Hilal-i Ahmer Hastanesi gibi yerlere vermesi sağlık hizmetlerindeki aksaklıkları minimize etmiştir. Millî Mücadele'de İsmet Bey'le birlikte Eskişehir-Uşak hattında önemli işlere imza atan Eczacı Binbaşı Salih Bey'e Vekâlet tarafından 12.000 lira avans tahsis edilerek ilaç alma yetkisi verilmiştir (DABCA, 1920). Bu sayede yurtdışındaki olanaklardan yararlanılarak Türkiye'den olmayan bazı ilaçlar Avrupa'dan tedarik edilmiştir.

Batı Cephesinde anahtar/kilit yerlerden biri olan Eskişehir'de, hastane dışında şehir istasyonu da farklı işlevler yerine getirmek için kullanılmıştır. Hilal-i Ahmer burada TBMM ve ordunun yükünü hafifleten etkinlikler gerçekleştirmiştir. İstasyondaki bekleme salonu "mecruh yuvası" olarak değerlendirilirken, yaralıların pansumanları sırasında onlara çay ve çorba dağıtılmıştır. İlk tedavileri istasyonda yapılan hafif ve orta derecede yaklaşık 2500 yaralı, daha sonra diğer hastanelere sevk edilmiştir (Çapa, 2006, s. 2). İstasyon çevresindeki Rum 
otellerinden de birer küçük hastane olarak faydalanılmıştır. Hilal-i Ahmer’in hastane dışında şehirde en çok hizmet verdiği ikinci yer istasyon olmuştur.

İnönü Muharebeleri'nde Türk Ordusunun zaferleri, Batı Anadolu'da tarafları neredeyse denk düzeye yaklaştırmıştı. Ancak Yunanlılar, hala saldırı yapabilecek güce sahiptiler. Yunan Ordusu, Kral Konstantin'in Mustafa Kemal Atatürk'ü "masadan sinek kovar gibi haritadan silme" hayalini gerçekleştirmek için 7 Temmuz'da Eskişehir-Ankara istikametine doğru yürüyüşe başlamıştır. Bunun üzerine Batı Cephesinde var olan genel sessizlik sona ermiştir (Hatipoğlu, 1988, s. 124, 125). "Vaziyet-i askeriyye" dikkate alınarak çok geçmeden operatör Pertev Bey riyasetinde bir heyet burakılarak Eskişehir Hilal-i Ahmer Hastanesi Kurşehir'e nakledilmiştir: "Eskişehir' in tahliyesine mecburiyet hâsıl olmasından ve Eskişehir Hastahânemizin Kırşehir'e nakli zarûri görülmesinden Ağustos 337 (M.1921) tarihinden itibaren mezkûr nekâhethâne hastahâne haline ifrağ olunmuştur” (Fettahoğlu, 2009, s. 41). Yunanlılar, Eskişehir'e girdikten sonra hastanede bırakılan az sayıdaki personel ve yaralıları mağdur etmişlerdir. Dönemin Başhekimi Safvet Bey’in hazırladığı raporda belirtildiği üzere bu insanlık dışı muamele karşısında hastaneden geriye kalanlar şehirdeki güvenli yerlere aktarılmıştır: "Yunanlıların beynelmilel yasaları çiğneyerek hastahaneyi bütün malzemesiyle kat-ı işgallerine almaları üzerine heyet hastahaneyi yaralıları ve kurtarabildiği akal-i kalil (azın azı) eşyasıyla Mekteb-i Sultani binasıyla civardaki camilere nakle mecbur kalmışlardır” (Çapa, 2006, s. 7).

İnönü Muharebeleri'nde büyük yararlılıklar gösteren Hilal-i Ahmer Hastanesi, Cumhuriyet'in ilk zamanlarında Memleket Hastanesi açlıncaya kadar 30.000 nüfuslu kazada tekrar hizmet vermeye başlamıştır (Yakut, 2015, s. 241). Yeni dönemde Türkiye'de modern şehirler inşa edilirken kurulan numune hastanelerinde, çalışma disiplini ve işleyişi açısından söz konusu sağlık kurumu model alınmıştır (Karabulut, 2007, s. 158).

\section{Hilal-i Ahmerin Sosyokültürel Etkinlikleri}

İnsanlık tarihinde toplumların oluşumundan itibaren onların dokusuna uygun çeşitli yardım kuruluşları ortaya çıkmıştır. Bu anlamda Türk toplumunun doğal kotlarıyla en çok örtüşen yardım teşkilatlarından biri de Hilal-i Ahmer Cemiyeti olmuştur. Sağlıkla ilintili bir kuruluş olmanın ötesine geçen Hilal-i Ahmer, mevcut olanaklar ölçüsünde her zaman ihtiyaç sahiplerinin yanında yer almıştır. Kendine özgün geçmişinde ırk ve inanç ayrımı yapmadan mağdur ve mazlumlara el uzatmayı şiar edinmiş cemiyet Osmanlıdan günümüze uluslararası bir saygınlık kazanmıştır. Bu tutumunu İnönü Muharebeleri sırasında da aynıyla sürdürmüştür (Anadolu Üniversitesi, 2009).

Vatan savunmasında büyük bir kahramanlık ve fedakârlık sergileyen Hilal-i Ahmer, yoksul kitlelere yardım (iane) ederken kurum olarak kendi de çeşitli bağışlar aracılığıyla ayakta kalmayı başarmıştır. Cemiyetin "hususi rozeti” dini bayram günlerinde özellikle ekonomik durumu iyi olan kişilere dağıtılmıştır. Bu şekilde elde edilen gelirler, İnönü Muharebeleri örneğinde olduğu gibi savaş yaralıların tedavisi ve şehit yakınlarının gereksinimleri için kullanılmıştır (DABOA, 1338). Hanımlar Şubesine mensup kadınlarda cemiyete ek gelir sağlamak için çeşitli etkinlikler düzenlemişlerdir. Kermes veya sergi açmak, kahramanlık türkülerinin okunduğu konserler tertip etmek, milli hissiyatın canlı kalmasını sağlayacak piyesler sahnelemek ve piyango bileti satmak bu etkinliklerin en belli başlıları idi. Birinci İnönü Muharebeleri sırasında sırf İstanbullu hanımlar yoksul ve yetimlere ulaştırmak için 500 lira toplamışlardır (Akgün ve Uluğtekin, 2001; Altay, 2008). Hanımlar Şubesi, Millî Mücadele boyunca daha önceden öğrenim görmek maksadıyla yurtdışına gitmiş Türk öğrencilerle aileleri arasında da iletişim kurmuştur. Bu konuda, Darülfünun Eminliği ve Hilal-i Ahmer Reisliği yapmış olan Dr. Besim Ömer Bey, hayli aktif görev almıştır. Hilal-i Ahmerin Kadınlar Kolunun açılmasına öncülük eden Besim Ömer Bey, Norveç, Almanya ve Fransa gibi ülkelerde eğitim gören Türklerin anayurtlarıyla bağlarının kopmamasına yardım etmiştir (DABOA, 1921; Ülman, 2005). 
İnönü Muharebeleri’nde verilen binlerce şehidin ardından zor durumdaki şehit ailelerine sürekli bir gelir kapısı aralamak için "iş yurdu" denilen bir birim meydana getirilmesi kararlaştırılmıştır. Böylece savaşın sosyoekonomik yaralarının daha hızlı sarılacağı düşünülmüştür (Sarıhan, 1993, s. 237). Eskişehir, Ankara, Kayseri ve Kırşehir'de ikamet eden şehit yakınlarının yanı sıra söz konusu illerdeki fakir vatandaşlarında temel ihtiyaçları karşılanmıştır. Hatta Hilal-i Ahmer bünyesinde sırf bu konularla uğraşacak bir komite tesis edilmiştir:

"Eskişehir ric'ati hasebiyle Ankara'ya gelen şühedâ ve zâbitân ve efrâd âilelerinin muhtâç-1 muâvenet (yardıma muhtaç) olanlarına, âile efrâdı adedine ve derece-i ihtiyâcına göre yirmi günlükten aşağı olmamak üzere i'âşe bedeli tevzî‘ edilmiş olduğu gibi, bir kısım halktan Kırşehir ve Kayseri'de bulunanlara da aynı sûretle muâvenet olunmuştur. Bundan başka en ziyâde muhtâç-1 muâvenet olanlara bir yere sevk edilinceye kadar her gün ekmek, çorba ve çay tevzi' olunmuştur” (Fettahoğlu, 2009, s. 92).

Cemiyet, düşman birliklerine esir (üsera) düşen Türklere Kur’an-1 Kerim dağıtırken (Kızılay Arşivi [KA], 1922) Anadolu ve Trakya'daki Hıristiyanlara da çeşitli insani yardımlar yapmıştır (Sarıhan, 1993, s. 532). Fakat muhtemel misyonerlik çalışmalarını engellemek içinse bir nevi paratoner görevi üstlenmiştir. Bu doğrultuda İcra Vekilleri Heyeti Riyasetince kabul edilen kararnameyle yurtta Hıristiyanlara ait "yardım” kulüplerinin faaliyet göstermesi yasaklanmıştır. Sadece Hilal-i Ahmer ve Amerika destekli Şark-1 Karib Muavenet Heyetinin (Ural, 2004, s. 135-147) muhtaç vatandaşlara el uzatabileceği belirtilmiştir (DABCA, 1922). Büyük önem arz eden kararnameyle Millî Mücadele sırasında yapılan yardımlar merkezileştirildiği gibi Cumhuriyet öncesinde Hilal-i Ahmerin geniş çaplı etkinlikleri yasal bir zemine oturtulmuştur.

Cemiyet hayır işlerinde son derece aktif olmasına rağmen kaotik ortam gereği kimi insanlar bağış yapmakta şüpheye düşmüşlerdi. Kafa karışıklığını gidermek içinse Türk Ordusunda Alay Müftülügü görevini yürüten Mehmed Nasuhi isimli bir din adamı basın yoluyla bazı açıklamalarda bulunmuştur. Din ve vatan uğruna mücadele edenleri koruyup kollayan Hilal-i Ahmere yapılacak her türlü bağışın İslam'da meşru/caiz olduğu belirtmiştir:

"Hilâl-i Ahmer Cem'iyet-i muhteremesi fukaraya her türlü mu'âvenet ve şefkati ibrâz ettiğine binâen Kur'ân1 Kerîm'de vârid olan "âmilîn" sınıfına, gâzilere her türlü mu'âvenet ve şefkati ibrâz ettiğine binâen de "fî sebîlillah" sınıfına dâhildir. Hilâl-i Ahmer Cem'iyeti hükûmet-i İslâmiye tarafından resmen musaddak bir hey'et-i mu'âvine ve müşfikadır. Zekât vesâir sadakâtı ahza me'mûr demek olacağı cihetle bu hey'et-i muhteremeye zekâtı vermek câiz olur" (Tevhîd-i Efkâr, 1337, s. 2). Böylesi bir beyan, tarihin her döneminde din adamlarına hürmet göstermiş Türk toplumu üzerinde epey olumlu bir etki bırakmıştır.

Millî Mücadele’nin “en büyük müessese-i hayriyyesi” olan Hilal-i Ahmer, İnönü Muharebeleri’nin yaşandığg 1921 yılından itibaren bir dergi yayınlamaya başlamıştır. Osmanlı Hilal-i Ahmer Mecmuası adıyla çıkartılan dergi saltanatın kaldırılmasından bir süre sonra Türkiye Hilal-i Ahmer Mecmuası adını almıştır:

“Merkezi Ankara'da bulunan TBMM kararıla Osmanlı Devleti’ne nihayet verilmesi ve saltanat-1 millîyenin teessüs etmesi üzerine 2 Teşrinisani 338 tarihine mütesadif Perşembe gününden itibaren Cemiyetimiz Türkiye Devleti ünvanına izafeten Türkiye Hilal-i Ahmer Cemiyeti ve mecmuamızın da Türkiye Hilal-i Ahmer Mecmuası adı resmiyet kesb etmiştir” (Türkiye Hilal-i Ahmer Mecmuası, 1337, s. 15).

Dergi savaşın seyri hakkında halkı bilgilendirmiştir. İkinci sayıda Birinci İnönü, beşinci ve altıncı sayıda ise, İkinci İnönü Muharebesi'ne geniş yer ayrılmıştır. Savaş sürecinin insanların ekonomik ve sosyal yapıları dışında sağlık durumunu da fazlasıyla etkilediğine değinilmiştir (Korkut, 2013, s. 92). Ekonomik durumları iyi olanlardan yardım istenmiştir. Hayırsever kişi ve kuruluşlardan 1921 yılı içinde toplanan 476.023 lira iane tutarında Hilal-i Ahmer Mecmuasının teşviklerinin önemli payı olmuştur (Müderrisoğlu, 2013, s. 311). Bu bağlamda Birinci İnönü'den sonra İstiklal Marşı yazarı Mehmet Akif te kendisine verilen 500 liralık ödülü Hilal-i Ahmer’in askerlere elbise diken Darü’l-mesai koluna bağışlamıştır (Çağbayır, 2009, s. 333). 
İnönü Muharebeleri sırasında Hilal-i Ahmerin toplumsal çalışmalarının bir bölümü de Hanımlar Merkezinin Balkan Savaşları'nda kurduğu Dâr-üs-Sanâ (Sanat Evi) birimi tarafından gerçekleştirilmiştir (Tepekaya ve Kaplan, 2003). Daru'ssınada başta göçmen kadınlar olmak üzere fakir hanımlara biçki, dikiş ve nakış kursları verilmiştir. Örgücülükte uzmanlaşan kadınlar, İnönü Muharebeleri’nde cephedeki askerlere çorap, çamaşır, eldiven ve battaniye dikmişlerdir. Böylece Mustafa Kemal Atatürk'ün her zaman tasarladığ 1 üretken Türk kadını olgusunun meydana gelmesine önemli ölçüde katkı sağlamışlardır (Akgün, 2021, s. 119).

Hilal-i Ahmer Cemiyeti, işgallerin başlamasından sonra İzmir-Ankara hattında onlarca karantina birimi, çayhane, aşevi, hastabakıcılık kursları, dispanser, nekâthane, sığınma evi ve barınak inşa etmiştir. Birçok okul, cami ve hastanenin tadilatını yaptırmıştır. Yaralı askerleri tedavi ederken kadın, çocuk, göçmen, hasta, yaşlı ve aciz durumdaki tüm insanların yanında yer alarak sosyal yaşamda terapi merkezi şeklinde faaliyette bulunmuştur. Osmanlı yönetiminin zafiyetlerle boğuştuğu, TBMM’nin de tüm sorunlara çözüm bulmaya çalıştığı evrede Hilal-i Ahmer, muktedir görünümlü bir kurum olarak sosyal meselelerin halli için ciddi anlamda uğraşmıştır.

\section{Hilal-i Ahmerin Dış Politikadaki Ağırlığı}

Cemiyet savaşı noktalandıran bazı antlaşmaların imzalanması, esir düşen Türklerin iadesi ve yurtdışından gelen yardımların toplanması sırasında gösterdiği etkinlikler sayesinde TBMM’nin diplomasideki yükünü kısmen de olsa azaltmıştır. Millî Mücadele'de en çetin direnişin sergilendiği yerlerden biri olan Güney Cephesi, Fransız ve Ermeni birliklerinin geri püskürtülmesinden sonra imzalanan 20 Ekim 1921 Ankara Antlaşması ile kapanmıştır (Soysal, 1974, s. 48-52). Bu antlaşmanın imzalanmasında ileri düzeyde Fransızca bilen Hilal-i Ahmerin II. Başkanı (Reis-i Sanisi) ve Başkan Vekili Hamid Bey Efendi’nin önemli katkısı olmuştur. İlk defa bir İtilaf devleti tarafından TBMM'nin resmen tanınmasını sağlayan 1921 Ankara Antlaşması'nın ardından Meclis, Hamid Bey Efendi ve Hilal-i Ahmere yayınladığı bir kararnameyle şükranlarını sunmuştur (DABCA, 1921).

İnönü Muharebeleri sırasında cemiyetin organize olmasına büyük yararlıklar sağlamış Hamid Bey Efendi, İngiltere ile TBMM arasında esir ve tutukluların karşılıklı değişimini konu alan 23 Ekim 1921 tarihli antlaşmanın imzalanmasına da öncülük etti (Doğanay, 2000, s. 76). Söz konusu antlaşma, TBMM'ye tepeden bakan İngiliz Hükümetinin bu tutumunu bırakmaya başladığının somut göstergesi idi. Antlaşmanın uygulama safhasında birtakım problemler çıksa da Hariciye Vekâleti ve Hilal-i Ahmerin sağduyulu politikaları sayesinde bunların hepsi tek tek aşılmıştır (ATASE, 1337; Osmanlı Hilal-i Ahmer Mecmuası, 1337).

Yunanlılar, İzmir' in işgalinden Sakarya Muharebesi’ne kadar olan süreçte binlerce Türk'ü esir almıştır. Bunlar içinde, yaşları 14 olan gençler de 70 yaşındaki ihtiyarlar da mevcuttu. Bir bölümü memur, bir bölümü esnaf bazıları ise öğrenciydi. Liyosa'daki kampta son derece sağlıksız ortamlarda yaşam mücadelesi veren Türk esirlerden vefat edenler dini merasim dahi yapılmadan gömülmüştür. Bu insanlık dışı durum Hilal-i Ahmer tarafından rapor haline getirilerek Uluslararası Kızılhaç Cemiyetine iletilmiştir:

"Memleketlerinde iş ve güçleriyle meşgûl iken, en küçük sebep ve bahâneler ile esîr sıfatıyla tutulup getirilen me'mûrîn-i devlet ile efrâd-1 milletten on dört on beş yaşlarındaki çocuklar ve yetmiş yaşındaki ihtiyârlar, Liyosa denilen üserâ karargâhında çadırlarda ve ekseriya topraklar üzerinde yatırılmakta ve bu bedbahtlar dahi hidemât-1 muhtelifede istihdâm edilmekte ve sonra buradan muhtelif mahallere sevk olunmaktadırlar. Hastahânelerde vefât eden Türk üserâsı hakkında dînen lâzım gelen hürmet îfâ edilmeyerek, cesetleri her türlü merâsim-i dîniyeden mahrûm bir hâlde Hristiyan mezârlıklarına defnedilmektedir" (Osmanlı Hilal-i Ahmer Mecmuas1, 1337, s. 98-100). 
Toplamda 13 maddelik rapordaki tespitlerin duyulmasının ardından dünya kamuoyunda Yunanistan'a sert tepkiler gösterilmiştir. Özellikle Amerika ve İskandinavya ülkelerindeki "insaf sahibi" bazı sivil toplum örgütleri Yunan Hükümetini protesto etmişlerdir (Özkan, 2016, s. 265-270).

Savaşlar sırasında yaptığı yardımlarla tüm dünyada takdir görmüş Hilal-i Ahmer, Millî Mücadele’de Türk tarafına büyük kayıplar verdiren Yunanlılar arasında dahi itibar kazanmıştı. Buradan hareketle, İstanbul'da Yunanistan'a ait komisyonun memurları, kendi ülkelerinde esir Türklerden hasta olanların Türkiye’ye getirilmesini istemişlerdir. TBMM İcra Vekilleri Heyeti ise, böyle bir görevi gizlilikle yerine getirmesi için uluslararası güven ve itibara sahip Hilal-i Ahmerin bir memurunu tayin etmiştir:

"İstanbul Yunan komisyonunun Dersaadette fevkalade komiserlerine bir nota ile müracaat ederek Yunanistan'daki Türk esirlerinden hasta olanlarının iade edilmek arzusunda olduğu cihetle bir murahhasla tayin-i rica olunduğu cihetle iktizasının tayin ve iş'arı Hamberk'den aksan-1 telgrafnamede bildirildiğine icabının taht-ı karara alınmış Hariciye Vekâletinin 3 Teşrinisani 337 (3 Kasım 1921) tarihli ve 3427 numaralı tezkirenin iş’ar olunmuş ve keyfiyeti İcra Vekilleri Heyetinin 5 Teşrinisani 337 (5 Kasım 1921) tarihli ihtiba'ında vürud tezekkür İstanbul'dan Hilal-i Ahmerden bir memur tayiniyle şu hasta üseranın aldırılması kararlaştırılmıştır” (DABCA, 1921).

Batı Anadolu'daki işgaller, İnönü Muharebeleri ve Kütahya-Eskişehir Savaşları'nda esir düşmüş Türklerden bakıma muhtaç derecede hasta durumda olanlar Hilal-i Ahmerin çabaları sonucu yurda geri getirilmiştir. Cemiyet, ulusal direniş yıllarında neredeyse bir Bakanlık kadar sorumluluk üstlenmiştir. Bu olağanüstü vaziyet Cumhuriyet'in ilanına kadar sürmüştür. Lozan Antlaşması (24 Temmuz 1923) hükümleri arasında yer alan Türk-Rum mübadelesi hayata geçirilirken de Hilal-i Ahmerden faydalanılmıştır (Arı, 2014, s. 67-70). Selanik ve Kavala'dan yurda nakledilen Türkler arasında görülen sıtma gibi bulaşıcı hastalıklara karşı cemiyet, Yunanistan Hükümetinin yapması gereken bazı sorumlulukları da yerine getirmiştir. Cemiyet azası Ömer Lütfü Bey, Sıhhiye Vekâletine yolladığı mektupta Hilal-i Ahmerin fedakârlıklarından bahsederken ekonomik destek talebinde bulunmuştur:

“Aşı yapılmak arzu edilirse Yunanistan'da irkâb iskelelerinde veyâhud vapurlarda yapmak kabildir. Heyetlerimizde bir mikdâr aşı mevcûddur. Hatta emrâz-1 sâriye zuhûru hâlinde nakledilecek muhâcirin istihmâm ve tathîri için Selanik ve Kavala'da tertîbât alınmışdır. Yalnız Hilâl-i Ahmer irkâb iskelelerinde dispanser, hastahâne ve (...) küşâdıyla esâsen programın hâricinde sarf-1 mesâ‘ îye mecbûr kaldığından emrâz1 sâriye zuhûru hâlinde tathîrât için masârıfı Yunan Hükûmetine âid olmak üzere hamâm ve etüv tahsîsi Muhtelit Komisyonca karâr verilmiş ise de bu mümkün olamadığı hâlde vekâlet-i celîlelerinden ayrıca tahsîsât ricâ edileceğini arz ve muhâcirler arasında pek çok sıtmalı mevcûd ve zâyiâtı mûceb olduğundan buna karşı tertîbât alınmasına müsâ‘adelerini ricâ ve cevâbınıza intizâr ederim” (KA, 1923).

Millî Mücadele Dönemi’nde çeşitli işkencelere maruz kalan insanları hastaneye çevirdiği gemiler ${ }^{4}$ aracıllğıyla kurtarıp güvenli yerlere nakleden Hilal-i Ahmer, dış devletlerden gelen yardımlar sırasında da insani ve milli ölçüleri esas alarak hareket etmiştir. İnönü Muharebeleri'nin hemen akabinde, o dönemde Avrupalı devletlerle arası açı olan Sovyetler Birliği, savaş mağdurları için kullanılması amacıyla TBMM’ye 30.000 altın Ruble yollamıştır. Bunun üzerine Mustafa Kemal Atatürk, Ankara'daki Sovyet temsilcisine çektiği bir telgrafla Türk milleti adına teşekkürlerini iletmiştir:

\footnotetext{
4 İkinci İnönü Muharebesi’nde elde edilen zaferden bir süre sonra Hilal-i Ahmerin temel ihtiyaç malzemeleriyle donattı̆̆ "Gülnihal” isimli vapur, Yunanlıların zulmettiği Türkler ve yerli Rumlar dışında Ege adalarındaki Muhacirlerin de imdadına yetişmiştir: "Gülnihâl vapuru dün sabah İzmit'e müteveccihen hareket etmiştir. Hilâl-i Ahmer tarafindan mezkûr vapurla 600 çuval un, 10,000 çadir ile külliyetli mikdârda mâlzeme-i sihhiye gönderilmiştir. Vapur, avdetini müte'âkıb (Limni, Saros, Sisam, Midilli) ada ve limanlarında bulunan muhâcirlerimizi nakle tahsîs edilecektir. Hilâl-i Ahmer Muhâcirîn Müdîriyeti'ne vâki' olan ihbara nazaran "Golos" şehrine iki bin nüfûsa karîb Müslümân hicret ettirilmiştir" (Tevhîd-i Efkâr, 1337, s. 2).
} 
"Mümessil Efendi, zaferimizin istihlas ettiği aksam-1 vatanda Yunan katliamlarında kurtulabilenlere verilmek üzere Hilal-i Ahmer' e teberru edilen 30 bin altın Ruble'den dolayı teşekküratı mahsusamı takdim ederim. Haris emperyalistlerle Rum vahşetinin en müthiş felakete sevk ettiği bu bedbahtlığa karşı Sovyet Rusya' nın bu hareketi alicenabane ve insaniyetkaranesi bütün milletimiz tarafından tamamen takdir edilecektir." (Atatürk'ün Tamim, Telgraf ve Beyannameleri, 1964).

Sovyetlerin hibe ettiği paranın 3000 altın Rublesi sivil halkın yararına kullanılması için doğrudan Hilal-i Ahmere devredilmiştir. Bizzat Mustafa Kemal Atatürk’ün cemiyete yolladığı mektupta yer alan ifadeler, bir Osmanlı kurumu olarak inşa edilen Hilal-i Ahmer ile Türk milletinin iradesini temsil eden TBMM arasındaki koordinasyon ve güveni açıkça ortaya koymuştur:

"Osmanlı Hilal-i Ahmer Cemiyeti Murahhaslığına: Bu defa Yunanlılar tarafından istila ve İkinci İnönü Muharebesi neticesinde terke mecbur edilmiş arazi dâhilinde felaketzede ahalimizin muhtac-1 muavenet olanlarına tevzi edilmek üzere Rusya Federatif Şuralar Cumhuriyeti Ankara Selahiyetdar Mümessilliği tarafından üç bin altın ruble iane verilmiştir. Meblağ-1 mezburun makbuz mukabilinde ahzıyla olvechile mahalline hüsn-i sarfıyla Riyasete malumat itasını rica ederim" (Atatürk'ün Tamim, Telgraf ve Beyannameleri, 1964).

Türklere karşı tarihten gelen derin bir bağlllık hisseden Hintli Müslümanlar, Millî Mücadele sırasında Hilal-i Ahmere hatırı sayılır miktarda yardımda bulunmuşlardır. Esasen söz konusu yardımlar, Trablusgarp Savaşı, Balkan Savaşları ve Birinci Dünya Savaşı yıllarında da yapılmıştır (DABOA, 1912). Ulusal direniş döneminde güneydoğu Asya üzerinden Hilal-i Ahmere takdim edilen bağışları kendileri de istiklal mücadelesi vermiş Muhammed Ali Cinnah ve Dr. Muhammed İkbal organize etmişlerdir (Keskin, 1991, s. 79-82). Hindistan Hilafet Komitesi, özellikle İnönü Muharebeleri’nden Cumhuriyet'e kadar olan evrede Türklere maddi destekte bulunmayı kendine görev addetmiştir. TBMM Hükümeti, Hindistan ve Pakistan'dan yapılan yardımların resmi yolla toplanmasını sağlamak için Türk Hilal-i Ahmerinin temsilcisi sıfatıyla Antalya Milletvekili Rasih Hoca'yı görevlendirmiştir. Rasih Hoca, Hilal-i Ahmer eliyle Millî Mücadele yararına kullanmak amacıyla toplanan 500.000 lirayı Mustafa Kemal Atatürk'e teslim etmiştir (Khan, 1993, s. 204). Bu yardımlar Uzakdoğu Müslümanlarının zihninde Türklerin gerçekleştirdiği bağımsızlık mücadelesinin Hilal-i Ahmer nezdinde sembolleştiğini kanıtlamıştır (Öke, 1988, s. 154). İngiltere ise, bu süreçte Hintli Müslümanların Türklere olan bağlılığını istihbarat faaliyetleri aracılığıyla farklı yanlara çekmeye çalışsa da bu politikasında başarılı olamamıştır (Gültekin, 2009, s. 78-80).

Türkiye'deki bağımsızlık mücadelesi birçok doğulu toplum tarafından örnek alınmıştır. Millî Mücadele onların özgürlük tutkularını da alevlendirmiştir. Mısır, Cezayir, Libya, Tunus, Filistin, Türkistan ve Kıbrıs'ta yaşayan Müslümanlar Anadolu'daki direnişi sahiplenerek desteklemişlerdir. Buralarda yaşayan yardımseverler topladıkları bağışları Hilal-i Ahmerle diyalog kurarak Türk yetkililerine belge karşıllı̆ında vermişlerdir (T.C. Başbakanlık Devlet Arşivleri Genel Müdürlüğü, 2007).

Hilal-i Ahmer, Kıbrıs Türklerince çok sevilen bir kurumdu. Bu yüzden Millî Mücadele'de sırasında Ada'da yaşayanlar cemiyet vasıtasıyla Anavatana yardımcı olmak için birbiriyle yarışmışlardır. Söz gazetesinin kurucusu Mehmet Remzi Bey, Hürriyet ve Terakki Kulübü, Muhacirîn-i İslamiye’ye Muavenet Cemiyeti ve bazı tarikatların dergâhları Hilal-i Ahmer lehine önemli etkinlikler düzenlemişlerdir (Memiş ve Köstüklü, 2008). Dini bayramların ilk günleri ve cuma günleri Kıbrıs'ta Hilal-i Ahmer günü ilan edilmiştir. Rumlar tarafından işkenceye maruz kalacağını bile bile birçok Türk, söz konusu günlerde elinden geldiği ölçüde Hilali Ahmere bağışta bulunmuştur. Köylerden toplanan yüklü miktarlardaki yardımlarda öğretmen ve imamların fedakâr gayretleri çok etkili olmuştur (Özoran, 1970, s. 923). Rumlar dışında İngiliz Hükümeti de Türklerin Hilal-i Ahmer için gerçekleştirdiği faaliyetleri engellemeye çalışmıştır. Fakat Hilal-i Ahmer, tüm girişimlere rağmen Kıbrıslı soydaşlarla sırt sırta vermeyi başarmıştır. 
Türkiye Türkleri ölüm kalım mücadelesi yaparken Türkistan'da da belirsizlik hâkimdi. Çoğu Türk beldesi 1920'li yılların başında Kızıl Ordu tarafından işgal edilmişti. Ancak Batı Türkistan'da Osman Kocaoğlu önderliğinde tesis edilen Buhara Halk Sovyet Cumhuriyeti (1920-1924) TBMM Hükümeti ile sıcak ilişkiler kurmuştur. İki Türk tarafı resmi olarak da birbirlerini tanımışlardır. Buharalı Türkler, Millî Mücadele süresince zaman zaman Mustafa Kemal Atatürk lehine gösteriler tertipleyerek ulusal direniş hareketine destekçi olduklarını kanıtlamışlardır. Topladıkları temel insani malzemeleri ve yüklü tutarlardaki altın Rubleleri ise, Hilal-i Ahmerle irtibata geçerek Türkiye’ye göndermişlerdir. Çünkü Buhara Cumhuriyeti’nin Türkiye'de o dönemde TBMM'den sonra muhatap aldığg kurumlardan biri de Hilal-i Ahmer Cemiyeti idi (https://www.tika.gov.tr/tr/haber/ozbekistandan_gelen_bir_haber-2465; Koçar, 1994). Buhara ve çevresinden tedarik edilen bağışlarda Türkistan bölgesinde dini ve milli duyguların diri kalması için çabalayan Enver Paşa'nın da büyük payı vardı. Sakarya zaferinin ardından Buhara Cumhuriyeti'nden bir heyet, Ankara'ya gelerek Mustafa Kemal Atatürk'ü ziyaret etmiş ve çeşitli hediyeler sunmuştur. Heyet aynı günlerde Ankara Hilal-i Ahmer Şubesiyle de temasa geçmiştir (Hatunoğlu, 2011, s. 112).

Anadolu milliyetçilerinin yürüttüğü bağımsızlık mücadelesi sırasında Hilal-i Ahmere çeşitli yardımlar yaparak cemiyete olan güvenini ortaya koyan ülkeler arasında Afganistan da yer almıştır. Birinci İnönü Muharebesi'nde elde edilen tarihi başarı başta Batılı devletler olmak üzere tüm dünya kamuoyunun dikkatini çekmiştir. İtilaf devletleri sürdüre geldikleri birtakım politikalarda esnemeye başlamışlardır. Bu zaman diliminde Afganistan'ın başında İngiliz emperyalizmine karşı gösterilen direnişin galibiyetle sonuçlanmasını sağlayan reformist Amanullah Han bulunmaktaydı. Mustafa Kemal Atatürk hayranı Amanullah önderliğindeki Afgan halkı, Millî Mücadele'ye hem askeri hem de mali açıdan çeşitli yardımlarda bulunmuştur. Hatta bazı Vilayetlerin Muhacirin İdaresine gönderilen Tahrirat Defterlerinde Afgan uyruklu askerlerin Anadolu'ya gelerek Türk Ordusu saflarında, işgalci kuvvetlere karşı direndiği belirtilmektedir (DABOA, 1340).

Birinci İnönü Muharebesi’nin akabinde Afganistan ile Ankara Hükümeti arasında 1 Mart 1921 "Dostluk ve İş Birliği Antlaşması" imzalanmıştır (ATASE, 1337). Antlaşma çerçevesinde Türk-Afgan kardeşliği daha da pekişmiştir. Yeni dönemde Afgan yetkililer, Balkanlardan Uzakdoğu'ya Türk Hilali Ahmerinin neler yaptıklarına doğrudan tanıklık etmişlerdir. Türkiye'deki Hilal-i Ahmer benzeri bir kurumu kendi ülkelerinde de tesis etmek için harekete geçerek cemiyetin nizamnamesi ve işleyişini düzenleyen talimatnameleri Türk yetkililerden istemişlerdir:

"Afganistan'da bir Hilâl-i Ahmer Cem iyeti teşekkül ettiğini haber vermiştik. Afgan Hilâl-i Ahmer'inin de Hilâl-i Ahmer’imiz misillü teşkîlatında muvaffakiyet ve intizâma mâlikiyeti için vukû‘ bulan talep üzerine Hilâl-i Ahmer teşkîlâtımıza âid îcâb eden ta 'lîmât ve nizâmnâmeler dün Afganistan’a gönderilmiştir” (Tevhîdi Efkâr: 1338).

Afganistan örneğinde olduğu Hilal-i Ahmer insancıl yapısı, savaşlar ve doğal afetlerde yaptığı yardımlar, sosyokültürel ve diplomatik alandaki etkinlikleriyle benzer kurumlar üzerinde derin tesirler bırakmıştır. Bu sayede cemiyet, misyonu itibariyle universal bir statü kazanmıştır.

Yüzyıllardır birçok Türk'ün mesken tuttuğu Bulgaristan'ın çeşitli bölgelerinden de Millî Mücadele’ye ekonomik yardımlar yapılmıştır. Hariciye Vekâleti ve Hilal-i Ahmerin müşterek çalışmaları sonucunda 19191922 yılları arasında temin edilen yardımlar 8000 Levayı bulmuştur (DABOA, 1922). Başta Varna, Sofya, Filibe ve Eski Cuma olmak üzere Müslüman/Türk nüfusunun yoğun yaşadığı yerlerde kurulan Hilal-i Ahmer komisyonları Anadolu'da olup bitenlerle ilgili halkı sık sık bilgilendirmiştir. Bulgaristan Türkleri, Hilal-i Ahmer Derc-i İane Heyetlerine para, sağlık malzemeleri, giyecek ve gıda maddeleri teslim etmişlerdir. Hariciye Vekâleti vasıtasıyla İstanbul ve Ankara ile iyi bir muhaberat kuran Bulgaristan'daki Hilal-i Ahmer görevlileri, toplanan her yardımı Türkiye'deki şube ve hastanelere ulaştırmışlardır. Bu yardımlardan İnönü Muharebeleri sırasından hayati öneme sahip Eskişehir Hilal-i Ahmer Hastanesi de nasiplenmiştir (Çapa, 2010, s. 74). 
Yunanistan'ın “Küçük Asya Seferi” sırasında deniz aşırı ülkelerde yaşayan Türkler ise, Anadolu coğrafyasına Hilal-i Ahmeri muhatap alarak birtakım yardımlar göndermişlerdir. Arjantin'in başkenti Buenos Aires'te, İnönü zaferlerinden sonra kurulmuş Hilal-i Ahmer Komitesi (Hilâl-i Ahmer Anadolu Cemiyeti Frrkasi) sadece ülkedeki Türk ve Müslümanlardan değil yerli halktan da destek görmüştür (Erdoğan, 2019, s. 73). Komitenin Başkanlığını Seyfeddin Recai Bey, II. Başkanlığını Necip Nasır Bey, Genel Sekreterliğini de Sadık Haşim Bey yürütmüştür (DABOA, 1921). İlk etapta toplanan 5000 Pezos doğrudan İnönü Muharebeleri’nde şehit düşenlerin aileleri ve savaşta yaralananlar için harcanmıştır. Komite ilerleyen dönemde de Millî Mücadele adına çeşitli yardım kampanyaları tertip etmiştir.

Ülke dışındaki Türkler, bulundukları yerlerde yaşayan Müslümanların da desteğini temin ederek çeşitli yardım dernekleri kurmuşlardır. Bunların Millî Mücadele adına topladığı bağışlar Hilal-i Ahmer vasıtasıyla Türkiye’ye aktarılmıştır. Özellikle Amerika'daki Türklerin çabaları başka yerlerde yaşayan Türklere iyi bir emsal olmuştur. New York, Filadelfiya, Providence ve Philadelphia'da Türklerin kurduğu derneklerin topladığ 1 yardımlar Ankara Hilal-i Ahmer Murahhaslığına yollanmıştır (Kutay, 1979, s. 140, 206). Bu sayede göçmenler ve yaralıların acil ihtiyaçları karşılanmıştır. Aynı süreçte Fransa, İtalya, İsveç ve İsviçre gibi ülkelerden de Hilali Ahmere itimat edilerek Türk istiklal davasına belli ölçüde destek çıkılmıştır (May, 2009).

\section{"Sözde İnsani" Hizmetler Sunan Bir Kuruluş: Yunan Salib-i Ahmer Cemiyeti}

Millî Mücadele Dönemi'nde Atatürk'ün ifadesiyle Türk milleti sırf "hayat ve istiklal için” (Ankara Üniversitesi, 1989) çabalarken karşısında kuvvetli bir müttefik/Haçlı grubu mevcuttu. Söz konusu grupta yer alan devletler, emperyalist hedeflere ulaşma uğruna Yunanlıları adeta maşa olarak kullanmışlardır. Bir taraftan Yunan Ordusuna her türlü silahı temin ederlerken diğer taraftan batık vaziyetteki Rum ekonomisini tabiri caizse suni teneffüs yoluyla diriltmişlerdir. Bu nedenle işgal yıllarında iki tarafın gücü kıyaslandığında Yunan birlikleri, Türk Ordusu karşısında hem mali ve hem de askeri açılardan hep üstün vaziyette olmuştur.

Batılı büyük devletlerin yardımlarıyla şımaran Yunanlıların, Anadolu'daki etkin kurumlarının başında Rum Salib-i Ahmer Cemiyeti/Örgütü yahut diğer ismiyle Yunan Kızılhaçı gelmiştir. Cemiyetin faaliyetleri Hilal-i Ahmerle mukayese edildiğinde Millî Mücadele'nin salt askeri olaylardan ibaret bir süreç olmadığı anlaşılmaktadır. Atina merkezli örgütün Mustafa Kemal Atatürk’ün de belirttiği gibi Türklere yapılan katliamları organize eden Mavri Mira Cemiyetiyle organik, İstanbul Rum Patrikhanesiyle ise inorganik bağları bulunmaktaydı:

“Bi'l-ahare elde edilen mevsûk ma'lûmât ve vesâik ile te'eyyüd etti ki, İstanbul Rum Patrikhanesi'nde teşekkül eden "Mavri Mira" heyeti vilayetler dâhilinde çeteler teşkil ve idare etmek, mitingler ve propagandalar yaptırmakla meşgul. Yunan Salib-i Ahmer-i, resmi Muhacirin Komisyonu; "Mavri Mira” heyetinin teshil-i mesa'isine hadim" (Atatürk, 2011, s. 6).

Yunan Devlet Başkanı Marko Renier öncülügünde 10 Haziran 1877’de kurulmuş Rum Salib-i Ahmer Cemiyetinin temel gayesi her şartta hasta, yaralı, göçmen/muhacir, yaşlı ve bakıma muhtaç kimselerin yanında yer almaktı (Sekili, 2019, s. 23). Ancak zaman içinde cemiyet, siyasetle iç dışlı olunca ana yörüngesinden sapmıştır. Türk topraklarının işgali sırasında Rum Salib-i Ahmerin ismi kanlı olaylar birlikte anılırken cemiyeti Albay Antiyas yönetmiştir (Güler, 1999, s. 88). Cemiyetin Anadolu ve Trakya'da, Hilal-i Ahmerin aksine asayişin bozulmasından Rum çetelerine silah nakletmeye, siyasi egemenmiş gibi davranmaktan ulaşım imkânlarını kötüye kullanmaya, savaş propagandası yapmaktan casusluk çalışmalarına kadar bir yığın olayda parmak izine rastlanmıştır. Bu haliyle cemiyeti bir yardım kuruluşu kabul etmek neredeyse imkânsız hale gelmiştir.

Yunanlılar özellikle Marmara, Ege ve Doğu Karadeniz bölgelerinde Rum çetelerini kışkırtarak halka büyük eziyetler yapmışlardır. Saldırgan politikalarını daha rahat hayata geçirmek içinde başta İzmir, İstanbul, 
Trabzon ve Samsun'da Salib-i Ahmer şubeleri açmışlardır (DABOA, 1337). Yunanistan'dan çeşitli vasıtalarla getirilen yağmacı zihniyete sahip kişiler Salib-i Ahmere dâhil edilince Anadolu'da kamu güvenliği iyiden iyiye bozulmuştur. Örneğin 21 Ağustos 1919 günü Salib-i Ahmer üyesi alkol almış bir Yunan vatandaşının Trabzon'da şehir merkezinde kontrolsüz biçimde havaya ateş açması şehirde ciddi gerginliğe neden olmuştur (DABOA, 1337). Oysa aynı dönemde Hilal-i Ahmere mensup görevliler, Trabzon ve çevresinde gerek Türk gerekse Rum yüzlerce insana sağlık hizmeti ulaştırmıştır.

İnönü Muharebeleri'nin gerçekleştiği mıntıkada da durum yukarıda bahsedilenlerden pek farklı değildi. Yunan Hükümeti ve Batılı devletlerin desteğini arkasına aldıkça yansızlığını yitiren Salib-i Ahmer, Batı Anadolu'da sadece Rum çetelerini değil Ermeni çetelerini de silahlandırarak Müslüman ahalinin can güvenliğini tehdit etmiştir. Yalova'dan Gemlik, Bursa, Bilecik, Sivrihisar ve Ankara'ya kadar uzanan bölgede İslam nüfusu çetelerin başıbozuk hareketlerinden dolayı hayli zor anlar yaşamıştır (DABOA, 1339). Bölgede bulunan sivil halkın imdadına yine Hilal-i Ahmer Cemiyeti koşmuştur. İnönü Muharebeleri'nin öncesi ve sonrasında iki cemiyetin tutumu aradaki farkı net bir şekilde göz önüne sermiştir. Zira Salib-i Ahmer doktor adı altında bölgeye askeri personel ve propagandist naklederken Hilal-i Ahmer ise, Eskişehir'deki hastanede olduğu gibi gönüllü hastabakıcı ve hemşire bulmanın derdine düşmüştür. Rum cemiyeti sandıklarla silah, bomba, askeri elbise ve cephane taşırken sadece insani gereksinimleri karşılamak için uğraşan Hilal-i Ahmer savaş mağdurlarına ilaç, çadır, battaniye ve yiyecek/hububat dağıtmıştır (Çapa, 2015; Güler, 1999).

Mondros Mütarekesi'nden hemen sonra Anadolu’ya yönelik emellerini açıkça ortaya koyan Yunanlılar, yüz yıllardır Türklerle bir arada yaşayan yerli Rumları kendi çıkarları doğrultusunda örgütlemişlerdir. Dikkat çekmemek içinde muhacirlerin yanı sıra Salib-i Ahmeri faaliyetlerine alet etmişlerdir (ATASE, 1338). Salib-i Ahmerin muhacirlerle birlikte Anadolu'nun her yerinde Rumlara silah dağıttığı 15. Kolordu Komutanı Kazım Karabekir tarafından Harbiye Nezaretine de iletilip bu konuda acilen tedbirler alınması gerektiği vurgulanmıştır (DABOA, 1337).

Bizans ve Pontus Rum devletlerini yeniden kurma mantalitesine hizmet eder hale gelen cemiyet, gün geçtikçe bir sağlık kurumu olma havasından uzaklaşmıştır. Yunanistan ve Ege adalarından taşınan komitecilerse gerilimi daha da tırmandırmaktan başka hiçbir işe yaramamıştır. Ocak 1920'de İzmir limanına demir atan Anfitrini adlı Salib-i Ahmerin hastane gemisinde önceki yıllarda İngiliz Ordusunda askerlik yapmış çete başları mevcuttu. Anadolu'nun içlerine nakledilen bu kişilerden bir bölümü İnönü Muharebeleri, Kütahya-Eskişehir Savaşları ve Sakarya Meydan Muharebesi'ne katılmışlardır (Bayar, 1997, s. 1610, 1611). Rum örgütünün menfi tutularına karşın Hilal-i Ahmer, savaşın önünü kesen teşebbüslerde bulunmuştur. Yukarıda da bahsedildiği üzere cephe kapatan veya esirlerin iadesini sağlayan antlaşmaların imzalanmasında cemiyetin üst düzey yöneticileri etkin rol oynamıştır.

Asayişi bozarak Yunan işgallerini haklı çıkartmaya çalışan Salib-i Ahmer, misyonerlik faaliyetlerinden de geri kalmamıştır. Cemiyet, bu nazik konuda derin bağlarının bulunduğu İstanbul Fener Rum Patrikhanesi ile müşterek hareket etmiştir. Ayriyeten Patrik Zaven'in Venizelos'la olan dirsek temasından dolayı bazı zamanlar İstanbul Ermeni Patrikhanesi ile de ortak adımlar atmıştır (Kılıç, 2008, s. 289). Siyasi otorite boşluğu nedeniyle hareket alanı genişleyen Fener Rum Patrikhanesi, işgal yıllarında neredeyse Yunan kilisesine dönüşmüştür. Patrikhanenin giriş kapısına Temmuz 1919'da Yunan bayrağının çekilmesi bu durumu somutlaştırmıştır (Sofuoğlu, 1994, s. 229). İlerleyen süreçte Patrikhane, Batı Anadolu'da açılmış Salib-i Ahmer hastanelerinin işleyişine bir şekilde müdahil olmuştur. Hastanelerde özellikle ekonomik durumu iyi olmayan insanlar ücretsiz tedavi edilirken karşılığında onlara bedava İncil dağıtılmış ve Rum halkının Anadolu toprakları üzerinki sözde tarihi haklarından bahsedilmiştir. Bir tür psikolojik harbi andıran bu davranışlar, 20.yüzyılın başında (19081915) Diyarbakır'da açılmış Amerikan Hastanesindeki yapılanlarla ciddi benzerlikler göstermektedir (Taşkın, 2017, s. 117). Nihai evrede her iki olayın failleri Anadolu’yu Hristiyanlaştırmak istemişlerdir. Ancak Hilal-i Ahmer gibi misyonerliğe karşı duruş sergileyen cemiyetler, halkın hassasiyetleri ve siyasi iradenin tavrı buna imkân tanımamıştır. 
Uluslararası antlaşmaların kendine tanıdığı hükümlerin dışına çıkan Salib-i Ahmer Cemiyeti, siyasetin o kadar çok içine dalmıştı ki, diplomatik ve askeri maharete sahip Venizelos önderliğinde Büyük Yunanistan’ı kurma hayaliyle gerçekleştirilmeye çalışlan "Yunan İhtilali" ni (Köylü, 2015, s. 45-46) dahi organize etmeye kalkışmıştır. Bu amaçla Anadolu'da siyasi parti gibi örgütlenip yerli Rumların desteğini almak için şubeler açmıştır. Venizelos ve askerlerinin mutlak suretle başarılı olmasını sağlama uğruna İnönü Muharebeleri’nin öncesi ve sonrasında cephedeki birliklere askeri mühimmat tedarik etmiştir. Silah ve mermi gibi malzemeleri illegal yollarla Anadolu'ya sokan Salib-i Ahmer “dünyadaki en meşru, en ahlaklı, en haklı, en kutsal savaşlardan biri olan Millî Mücadele” (Özakman, 2007, s. 687) sırasında bir nevi silah kaçakçllı̆̆ yapmıştır (DABOA, 1919).

İzmir'in işgali ile Birinci İnönü Muharebesi arasında Batı Anadolu'da hızla örgütlenen Salib-i Ahmer, Bizans İmparatorluğu hayalindeki Yunan Kraliyet ailesinden önemli ölçüde destek görmüştür. 21 Ağustos 1920 günü İzmir'e gelen Yunan Kraliçesi, heyet-i murahhasların açtığı bölgedeki Salib-i Ahmer Cemiyeti hastanelerini tek tek ziyaret etmiştir. Aydın Vali Vekilinin Dâhiliye Nezaretine yolladığı yazıda, Kraliçenin teşkilat merkezine dönüşmüş hastanelerde tedavi gören Yunan-Rum subay ve askerlerinin motivasyonunu üst düzeye çıkarmaya çalıştığı anlaşılmaktadır (DABOA, 1338). Böyle bir ziyaret, Yunanlıların Türklere karşı nasıl ciddi bir savaş hazırlığı yaptığını ortaya koymuştur. Aynı bölgede faaliyet gösteren Hilal-i Ahmer imdat heyetleri ise, siyasi yetkililerden bağımsız olarak işgaller nedeniyle sadece yardımlarla ayakta kalıp her ihtiyaç sahibinin yanında olmuştur. İşgallerin yol açtığı sosyal yaraları da ortadan kaldırmaya çalışmışlardır.

İnönü Muharebeleri ve sonuçlarını önemli kılan konulardan biri de esirlerin karşılıklı değişimi meselesiydi. Sorunu çözüme kavuşturmak adına Hilal-i Ahmerle, Yunan Salib-i Ahmer arasında gerçekleşen görüşmelerden bir sonuç alınmamış ve taraflar bir türlü mutabakata varamamıştır. Bunun üzerine devreye uluslararası Kızılhaç komitesi girmiştir. Kızılhaç, hem Türkiye hem de Yunanistan'daki esir kamplarının durumunu yerinde gözlemlemek için heyetler meydana getirmiştir. İlk olarak, İnönü ve Sakarya Muharebeleri'nden sonra Kızılhaç görevlisi Dr. A.W. Roerich, İstanbul'a gelmiş ve buradan esirlerin yaşadığı yerleri görmeye geçmiştir (Çapa, 1990, s. 281). Dr. Roerich sırasıyla Mersin, Kayseri (Talas) ve Ankara'daki esir garnizonlarıyla yine Ankara'da hizmet veren Hilal-i Ahmer Hastanesini teftiş etmiştir. Yanında Hilal-i Ahmeri temsilen Mehmet Tahir Bey bulunmuştur. Kamplarda ikamet edenlere Hilal-i Ahmer çamaşır, çorap ve fanila dağıtıp onların temel gereksinimlerini anında karşılamıştır (KA, 1338). Türk konuk severliğinden ve kamplardaki yaşam koşullarından gayet memnun kalan Dr. Roerich şu tespitlerde bulunmuştur: "Garnizonlar adeta bir sanatoryum idi. Esirler hastanelerde Türk hastalarıyla beraber bulunuyor ve aynı yemekten yiyorlardı" (Hâkimiyeti Millîye, 1338, s. 2).

Türkiye'deki Yunan esirleri Hilal-i Ahmer sayesinde insanca bir hayat sürerken aynı durum Yunanistan'daki Türk esirler için geçerli değildi. Kızılhaç adına Yunanistan'daki Türk esirlerin hangi şartlarda barındığını saptamak için bu ülkeye giden İsviçreli Dr. Paul Schatzmann bir rapor hazırlamıştır. Raporda Türk esirlerin yiyecek, giyecek ve ilaç ihtiyaçlarının bulunduğu belirtmiştir. Salgın hastalıklarla boğuşan Türklere "kamp görevlilerince şiddet uygulanmakta" olduğunu dile getirmiştir (KA, 1338). Onların Türkiye'deki aileleriyle irtibatları Hilal-i Ahmer aracılığıyla sağlanmıştır. Yunan Salib-i Ahmer Cemiyeti ise kendi ülkesindeki sivil Türklerin temel sorunlarıyla ilgilenmemiş ve topladığı bağışları savaşta kullanmıştır (Akandere, 2000, s. 450). Kızılhaç, 1923’te de her iki ülkeye esirlerin durumu hakkında tekrar heyet yollamıştır.

Salib-i Ahmerin 1919-1923 yılları arasında Anadolu ve Trakya'da etkinlik göstermiş olması uluslararası Kızılhaç örgütünün temel ilkeleriyle örtüşmemekteydi. Çünkü Kızılhaç, "birlik prensibi” ne göre bir ülkede sağlık hizmetlerinin tekelden yönetilmesi gerektiğini deklare etmişti. Bu nedenle Hilal-i Ahmer idare heyeti, 1 Mayıs 1919 günü Yunan Salib-i Ahmerin Türkiye'deki çalışmalarına son vermesini kararlaştırmıştır (Özcan, 2011, s. 702, 703). Alınan karar Batı Anadolu'daki şubelerine tebliğ olunmasına rağmen Salib-i Ahmer, illegal faaliyetlerini ara vermeden devam ettirmiştir. 


\section{Sonuç}

Millî Mücadele'deki en hassas gelişmelerden olan İnönü Muharebeleri, sırf askeri başarılar ve bu başarıların diplomatik alanda doğurduğu sonuçlar ekseninde değerlendirilmemelidir. Türk tarafı, bu muharebelerde sağlık hizmetleri ile sosyal dayanışma alanlarında yaşanan gelişmelerden gerekli dersleri çıkarmış ve bunu ilerleyen sürece olumlu şekilde yansıtmıştır. Bir dilim kuru ekmeğin, bir çift çorabın, bir sargı bezi ve tentürdiyotun zor bulunduğu yıllarda Hilal-i Ahmer takdire şayan bir şekilde organize olmuştur. Bu yardımseverlik ve teşkilatçılık ruhu, bugünde Türk Kızılayı tarafından kıtalararası şekilde sürdürülmektedir. Ulusal direniş yıllarında emperyalistlerin güdümüne girmiş Rum Salib-i Ahmer örgütüyse tarafsızlı̆ğ tamamen bir yana bırakmıştır. Türk topraklarında doğrudan ya da dolaylı yoldan insanların katledilmesinde etkin rol oynamıştır. Buradan hareketle hiç ilgisiz şekilde eğitim, sağlık ve dayanışma görüntüsü altındaki zararlı yapılanmaların 21.yüzyılda da barışı zedelemesi kuvvetle muhtemeldir. Özellikle kamu düzenini sağlamakla sorumlu birimler bu konuda ihtiyatı hiçbir zaman elden bırakmamalıdır.

\section{Kaynakça}

Adıvar, H. (2019). Türk’ün ateşle imtihanı: İstiklal Savaşı hatıraları. İstanbul: Can Yayınları.

Akandere, O. (2000). 1923 yılı ortalarında uluslararası Kızılhaç komitesince görevlendirilen heyetin Anadolu'daki teftiş gezileri ve hazırladıkları rapor. Atatürk Araştırma Merkezi Dergisi, 18(53), 443-469. Erişim adresi: https:/www.atam.gov.tr/wp-content/uploads/Osman-AKANDERE-1923Y\%c4\%b1l\%c4\%b1-Ortalar\%c4\%blnda-Uluslar-Aras\%c4\%b1 $\quad$ K\%c4\%b1z\%c4\%b1lha\%c3\%a7Komitesince-G\%c3\%b6revlendirilen-Heyetin-Anadoludaki-Tefti\%c5\%9f-Gezileri-ve.pdf

Akduran, R. (1999). Türkiye Cumhuriyeti'nin 75.y1lında Türkiye'de sağlık politikaları. Türkiye Cumhuriyeti'nin 75. yılında bilim "bilanço 1923-1998" ulusal toplantısı (s. 47-60) içinde. Ankara: Türkiye Bilimler Akademisi.

Akgün, S. K. (2012). Cumhuriyet duyurulurken geride birakılamayan bir kurum: Hilal-i Ahmer cemiyeti. ODTÜ Gelişme Dergisi, (39), 111-136. Erişim adresi: http://www.ajindex.com/dosyalar/makale/acarindex-1423909927.pdf

Akgün, S. K. ve Uluğtekin, M. (2001). Hilal-i Ahmer'den Kızılay’a. Ankara: Kızılay Yayınları.

Akşam Gazetesi (4 Nisan 1337). Drahmin baş aşağı. S. 763, s. 1.

Akşin, S. (2017). İç savaşve Sevr'de ölüm. İstanbul: Türkiye İş Bankası Kültür Yayınları.

Altay, F. (2008). 10 Yıl savaş ve sonrası 1912-1922. İstanbul: Eylem Yayınları.

Anadolu'da Yeni Gün Gazetesi (3 Nisan 1337). Eskişehir darü’l-tedavisinin hekimleri, S. 470, s. 1.

Anameriç, H. (2010). Türk Kızılayı'nın (Osmanlı Hilal-i Ahmer cemiyeti) savaş esirlerine kitap ve kütüphane hizmetleri (1912-1922). Erdem, (58), 20-43. Erişim adresi: https://dergipark.org.tr/tr/download/articlefile/669967

Ankara Üniversitesi. (Der: Nimet Arsan). (1964). Atatürk'ün tamim, telgraf ve beyannameleri. Cilt 4, Ankara. Ankara Üniversitesi. (1989). Atatürk’ün söylev ve demeçleri. Cilt 2, Ankara.

Arı, K. (2014). Büyük mübadele Türkiye’ye zorunlu göç 1923-1925. İstanbul: Tarih Vakfı Yurt Yayınları.

Arslan, N. O. (2010). Hilal-i Ahmer cemiyeti’nin çalışmalarından bazı kesitler. Atatürk Dergisi, 4(2), 219-236.

Erişim adresi: https://dergipark.org.tr/tr/pub/atauniad/issue/2362/30290 
Atatürk, M.K. (2011). Nutuk. (Yay. haz. Şefik Memiş ve İsmail Şen). İstanbul: Tıpkıbasım-Çevrimyazı.

Atase, İst. H. Kls. Kls. No: 694, 7901, 75. 8, s. 1.

Atase, İst. H. Kls. Kls. No: 1389, 173, 13-8, s. 1.

Atase, İst. H. Kls. No: 84, 36-1, s. 1.

Atase, İst. H. Kls. Kls. No: K:1083, G:10, B:10-1, s. 1-3.

Bayar, C. (1997). Bende yazdım. İstanbul: Sabah Kitapları Yayınları, Cilt 2, 5.

Bele, T. (2010). Halide Edip Adıvar'ın hayatı. İstanbul: Siyah Beyaz Yayınları.

Çağbayır, Y. (2009). Bayrak mücadelemiz ve İstiklal Marşı. İstanbul: Ötüken Yayınları.

Çapa, M. (1990). Millî Mücadele yıllarında Anadolu'daki Yunan savaş esirlerini ziyaret eden uluslararası ilk Kızılhaç heyeti. Atatürk Yolu Dergisi, 2(6), 281-294. Erişim adresi: https://dergipark.org.tr/tr/pub/ankuayd/issue/1875/22761

Çapa, M. (2006). Millî Mücadele’de Eskişehir Kızllay (Hilal-i Ahmer) hastanesi ve Yunan işgali. Askeri Tarih Araştırmaları Dergisi, $\quad$ (8), $\quad 1-37 . \quad$ Erişim adresi: http://cv.ankara.edu.tr/kisi.php?id=capa@ankara.edu.tr\&deger=1

Çapa, M. (2010). Kızılay (Hilal-i Ahmer) cemiyeti (1914-1925). Ankara: Türkiye Kızılay Derneği Yayınları.

Çapa, M. (2015). Millî Mücadelede döneminde İzmir ve çevresinde Kızılay (Hilal-i Ahmer)'in faaliyetleri. Kurtuluşve kuruluşu sembol kenti İzmir sempozyumu 2012 (s. 53-68) içinde. Ankara: Atatürk Araştırma Merkezi Yayınları.

Dabca, 3.3.1920, 272-0-0-14/ 73-23-15, s. 1, 2.

Dabca, 27.7.1920, 30-18-1-1/ 1-6-18, s.1 (EK-2'ye bkz).

Dabca, 15.11.1920, 30-18-1-1/1-19-7, s. 1 (EK-3'e bkz).

Dabca, 29.6.1921, 30-18-1-1/ 3-27-11, s.1 (EK-1'e bkz).

Dabca, 2.11.1921, 30-18-1-1/3-35-3, 51-6, s. 1 (EK-6'ya bkz).

Dabca, 8.11.1921, 30-18-1-1/4-36-14, 438-3, s. 1 (EK-5'e bkz).

Dabca, 28.6.1922, 30-18-1-1/5-19-4, 239-7, s. 1 (EK-4'e bkz).

Daboa, 27.11.1912, HR.TO.. , 543-21, s. 1, 2.

Daboa, 29,11,1919, HR.SYS. 2714-16, s. 1.

Daboa, 5.4.1921, HR. SYS. , 2702-3, s. 1, 2, 21.

Daboa, H.19.9.1337, 00053.1.00069.001, s.5.

Daboa, 24.11.1337, DH.EUM.ECB. , 37-10, s. 2, 65.

Daboa, 18.12.1337, DH.KMS. , 55-7, s. 4 (EK-7’ye bkz).

Daboa, 30.12.1921. H.R.İ.M.., 59-26, s. 1.

Daboa, 27.2.1922, HR.SFR.04.. , 926-20, s. 1-3.

Daboa, 26.9.1338, DH.İ.UM. , 11-6, s. 1-4.

Daboa, 6.12.1338, DH.İ.UM. 20-14, s. 3 (EK-8’e bkz). 
Daboa, 22.11.1339, DH.KMS. , 60-55, s. 3.

Daboa, 15.5.1340, DH.SN.., THR. /89-43, s. 1.

Dirican, M. R. (1970). Türkiye’de sağlık hizmetlerinin örgütlenmesinin kısa tarihçesi. Atatürk Üniversitesi Tıp Fakültesi Tip Bülteni, $2(7), \quad$ 184-193. Erişim https://www.eajm.org/content/files/sayilar/36/buyuk/3.pdf

Doğanay, R. (2000). Millî Mücadele’de Türk-İngiliz esir değişimi. Fırat Üniversitesi Sosyal Bilimler Dergisi, 10(1), 69-78. Erişim adresi: http://web.firat.edu.tr/sosyalbil/dergi/arsiv/cilt10/sayi1/069-078.pdf

Erdeha, K. (1975). Millî Mücadelede vilayetler ve valiler. İstanbul: Remzi Kitabevi.

Erdoğan, R.T. (2019). Yeni Türkiye vizyonu ezberleri bozarken-4. Ankara: Cumhurbaşkanlığı Yayınları.

Gaulis, B. G. (1981). Kurtuluş Savaşı sırasında Türk milliyetçiliği. (Çev. C. Yazansoy). İstanbul: Rado Yayınları. Genelkurmay Başkanlığı. (1995). Türk İstiklal harbi batı cephesi. Ankara, Cilt 2, Kitap: 3.

Genelkurmay Başkanlığı. (2000). İnönü muharebeleri: Harp tarihi broşürü. Ankara.

Güler, A. (1999). Dünden bugüne Yunan-Rum terörü. Ankara: Ocak Yayınları.

G. A. (2009). Millî Mücadele Dönemi’nde Hindistan Müslümanları ile Ankara hükümetleri arasındaki münasebetler (1918-1924) (Yayımlanmamış yüksek lisans tezi). Balıkesir Üniversitesi Sosyal Bilimler Enstitüsü, Balıkesir.

Güneş, İ. ve Yakut, K. (2007). Osmanlı'dan Cumhuriyet'e Eskişehir (1840-1923). Eskişehir: Anadolu Üniversitesi Yayınları.

Hacıfettahoğlu, İ. (2009). Millî Mücadele’de Hilal-i Ahmer Türkiye Büyük Millet Meclisinin teşkilinden Sakarya zaferine kadar Hilâl-i Ahmer cemiyeti icraat raporu 23 Nisan 1920 - 23 Eylül 1921. Ankara: Türkiye Kızılay Derneği Yayınları.

Hâkimiyeti Millîye Gazetesi (10 Nisan 1337). Hilal-i Ahmer’in Ankara'daki darü’l-tedavi şubesi. S. 151 , s. 2.

Hatipoğlu, M.M. (1988). Yunanistan'daki gelişmelerin ışı̆̆ında Türk-Yunan ilişkilerinin 100 yılı (1821-1922). Ankara: Türk Kültürünü Araştırma Enstitüsü Yayınları.

Hatunoğlu, N. (2011). Türkistan'da son Türk devleti Buhara emirliği ve Âlim Han. İstanbul: Ötüken Neşriyat. https://www.tika.gov.tr/tr/haber/ozbekistandan_gelen_bir_haber-2465 (Erişim Tarihi: 21.12.2020).

Ka, 7.2.1922, Kutu: 529, No: 330, s. 1, 2 .

Ka, 24.2.1338, Kutu: 1223, No: 270, s. 1, 2.

Ka, 8.3.1922, Kutu: 559, No: 277, s. 1.

Ka, 1923 (tarih tam olarak belli değil), Kutu: 1297, No: 2020, s. 1.

Karabulut, U. (2007). Cumhuriyet'in ilk yıllarında sağlık hizmetlerine toplu bir bakış; Dr. Refik Saydam’ın sağlık bakanlığı ve hizmetleri (1925-1937). Çă̆daş Türkiye Tarihi Araştırmaları Dergisi, 6(15), 151-160. Erişim adresi: https://dergipark.org.tr/tr/pub/cttad/issue/25238/266821

Karadağ, R. (2005). Şark meselesi. İstanbul: Emre Yayınları.

Keskin, M. (1991). Hindistan Müslümanlarının Millî Mücadele Türkiye’ye yardımları (1919-1923). Kayseri: Erciyes Üniversitesi Matbaası. 
Khan, A. A. (1993). Hint Müslümanlarının Türk kurtuluş hareketine mali yardımı 1919-1923. Tarih İncelemeleri Dergisi, (8), 203-217. Erişim adresi: https://dergipark.org.tr/tr/pub/egetid/issue/5035/68579

Kocatürk, U. (1998). Atatürk ve Türkiye Cumhuriyeti tarihi kronolojisi (1918-1938). Ankara: TTK Yayınları.

Koçar, Ç. (1994). Çukurova’nın kurtuluşuna iştirak eden Türkistanlılar. XI. Türk tarih kongresi 5-9 Eylül 1990 (s. 2377-2383) içinde.

Korkut, H. (2013). Anadolu'da harp yılları, Hilal-i Ahmer mecmuası ve dönemin toplumsal sorunları. Tarih Kültür ve Sanat Araştırmaları Dergisi, 2(3), 90-99. Erişim adresi: http://kutaksam.karabuk.edu.tr/index.php/ilk/article/view/244

Köstüklü, N. (2008). Millî Mücadele'de Akşehir. Atatürk Araştırma Merkezi Dergisi, 24(71), 299-318. Erişim adresi: https://dergipark.org.tr/tr/pub/aamd/issue/44088/543242

Köylü, M. (2015). Yunan siyasi tarihinde siyasal çalkantıların (1909-1922) İstiklal Harbine etkisi. Toros Üniversitesi İktisadi, İdari, Sosyal Bilimler Fakültesi Sosyal Bilimler Dergisi, 2(4), 31-56. Erişim adresi: https://dergipark.org.tr/tr/pub/iisbf/issue/27277/287160

Kılıç, D. (2008). Tarihten günümüze İstanbul Ermeni patrikhanesi. Ankara: Atatürk Araştırma Merkezi Yayınlar1.

Kutay, C. (1979). Türk Millî Mücadelesinde Amerika. İstanbul: Boğaziçi Basım ve Yayınevi.

May, H.M. (2009). Türk Kurtuluş Savaşının finansmanı. Mevzuat Dergisi, (133). Erişim adresi: www.mevzuatdergisi.com

Müderrisoğlu, A. (2013). Kurtuluş Savaşının mali kaynakları. Ankara: Atatürk Araştırma Merkezi Yayınları.

Osmanlı/Türkiye Hilal-i Ahmer Mecmuası (1337).

Öke, M. K. (1988). Güney Asya Müslümanları'nın istiklâl davası ve Türk Millî Mücadelesi "hilâfet hareketi" (1919-1924). Ankara: Kültür ve Turizm Bakanlığı.

Özakman, T. (2007). Şu çılgın Türkler. İstanbul: Bilgi Yayınevi.

Özcan, L. (2011). Türk Kızılay müessesesinin Cenevre Sözleşmelerini gaye olarak kabul etmiş olması ve milletlerarası Kızılhaç doktrini (prensipler). İstanbul Üniversitesi Hukuk Fakültesi Mecmuası, 32(2-4), 693-714. Erişim adresi: https://dergipark.org.tr/tr/pub/iuhfm/issue/9099/113720

Özkan, K. (2016). Millî Mücadele dönemi Türkiye-ABD ilişkileri. İstanbul: Ötüken Neşriyat.

Özoran, B. R. (1970). Anadolu Kurtuluş Savaşı yıllarında Kıbrıs'ta Türk basını. VII. tarih kongresi (s. 910-951) içinde. Ankara: TTK Yayınevi.

Safi, P. (2009). Kurtuluş ve aydınlanma: Eskişehir arşiv belgeleriyle. Ankara: Anadolu Üniversitesi Yayını.

Sağlık ve Sosyal Yardım Bakanlığı. (1973). Sağlık hizmetlerinde 50 yıl. Ankara.

Sarıhan, Z. (1993). Kurtuluş Savaşı günlüğü. Ankara: TTK Yayınevi, Cilt 1, 3, 4.

Sekiki, A. (2019). Yunan Salib-i Ahmer cemiyeti’nin Trakya'daki faaliyetleri. ÇKÜ Sosyal Bilimler Enstitüsü Dergisi, 10(2), 20-36. Erişim adresi: https://dergipark.org.tr/tr/pub/jiss/issue/50416/558667

Selek, S. (2006). İsmet İnön̈̈ / hatıralar. İstanbul: Bilgi Yayınevi.

Selışık, S. (2006). Türk İstiklâl Savaşı'nda Birinci İnönü Muharebesi. Ankara: Genelkurmay Basımevi. 
Sofuoğlu, A. (1994). Anadolu üzerindeki Yunan hedefleri ve Mütareke dönemi Fener Rum Patrikhanesi'nin faaliyetleri. Atatürk Araştırma Merkezi Dergisi, 10(28), 211-256. Erişim adresi: https://dergipark.org.tr/tr/pub/aamd/issue/55355/759334

Sofuoğlu, A. ve Yıldırım, S. (2018). Arşiv vesikalarına Göre 1921 Londra Konferansı tutanaklar-belgeler. Ankara: Atatürk Araştırma Merkezi Yayını.

Soysal, İ. (2000). Türkiye’nin siyasal andlaşmaları (1920-1945). Ankara: TTK Yayınevi, Cilt 1.

Taşkın, F. (2017). Diyarbakır'da bir misyoner hastanesi: Diyarbakır Amerikan hastanesi (1908-1915). Journal of History and Future, 3(3), 110-122. Erişim adresi: https://dergipark.org.tr/tr/pub/jhf/issue/32767/350134

T.C. Başbakanlık Devlet Arşivleri Genel Müdürlüğü. (2007). Osmanlı belgelerinde Millî Mücadele ve Mustafa Kemal Atatürk. Ankara.

Tepekaya, M. ve Kaplan, L. (2003). Hilal-i Ahmer hanımlar merkezinin kuruluşu ve faaliyetleri. Selçuk Üniversitesi Sosyal Bilimler Dergisi, (10), 147-202. Erişim adresi: http://dergisosyalbil.selcuk.edu.tr/susbed/article/view/760

Tercümân-1 Hakîkat Gazetesi (6 Temmuz 1337). Fedakâr hanımlar. S. 14463, s. 1.

Tevhîd-i Efkâr Gazetesi (5 Haziran 1337). Alay müftüsü: Hilâl-i Ahmer’e zekat vermek caizdir. S. 3, s.2.

Turan, M. (1996). İzmir'in işgali üzerine. Atatürk Araştırma Merkezi Dergisi, 12(36), 739-753. Erişim adresi: https:/www.atam.gov.tr/wp-content/uploads/Mustafa-TURAN-\%c4\%b0zmirin-\%c4\%b0\%c5\%9fgali$\%$ c3\%9czerine.pdf

Turan, M. (2006). Yunan mezalimi: İzmir, Aydın, Manisa, Denizli 1919-1923. Ankara: Atatürk Araştırma Merkezi Yayını.

Türk Kızılay Derneği (1950). Türkiye Kızılay Derneği 73 yıllık hayatı 1877-1949. Ankara.

Türkmen, Z. (2016). Devlet merkezine gönderilen raporlara göre Batı Anadolu'da Yunan mezalimi. Ankara: Berikan Yayınevi.

Uluğtekin, M. ve Uluğtekin, M. G. (2013). Osmanlidan Cumhuriyet'e Hilal-i Ahmer icraat raporları 19141928. Ankara: Türk Kızılayı Yayını.

Ural, S. (2004). Amerikan Yakın Doğu yardım cemiyeti’nin (Şark-i Karib muavenet cemiyeti) çalışmaları. Selçuk Üniversitesi Ata Dergisi, (12), 135-147. Erişim adresi: https://www.academia.edu/40011753/Amerikan_Yak\%C4\%B1ndo\%C4\%9Fu_Yard\%C4\%B1m_Cemiy etinin_\%C5\%9Eark_i_Karib_Muavenet_Cemiyeti_\%C3\%87al\%C4\%B1\%C5\%9Fmalar

Ülman, Y.I. (2005). Osmanlı'dan Cumhuriyet'e geçiş sürecinde bir aydının portresi (1861-1940) Dr. Besim Ömer Akalın. Yeni Tip Tarihi Araştırmaları Dergisi, 5(11), 435-464. Erişim adresi: https://www.researchgate.net/publication/269221568_Osmanlidan_Cumhuriyete_Gecis_Doneminde_ bir_aydinin_portresi_The_portrait_of_an_elite_during_the_transformation_from_the_Ottoman_Em pire_to_the_Turkish_Republic_Besim_Omer_Akalin_1861-1940

Yakut, K. (2015). Modern Eskişehir’in doğuşu. Ankara: Kebikeç Yayınları. 


\section{Ekler}

20

;

$\cdots$

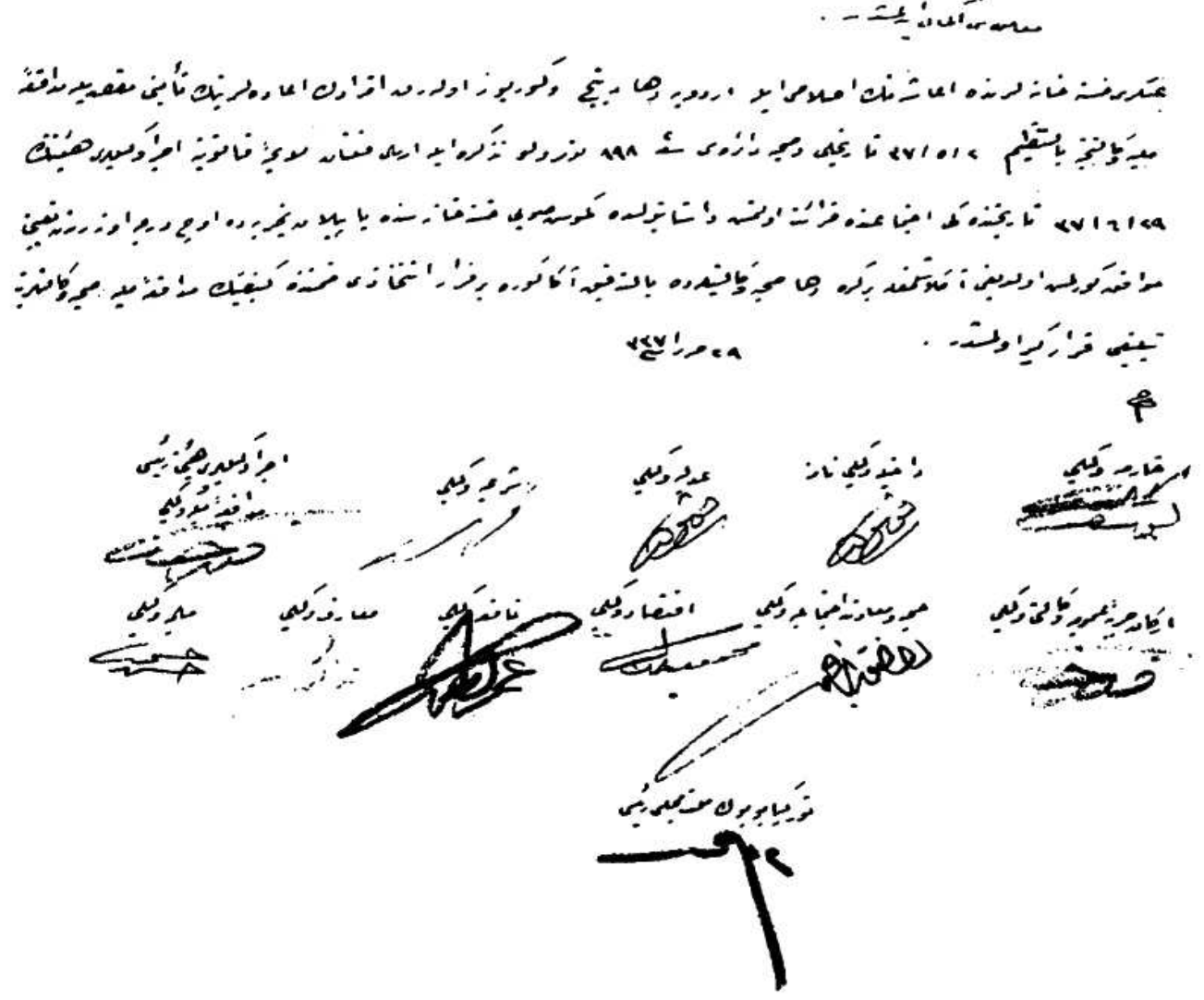

EK-1: Çoğunluğu Hilal-İ Ahmer Çalışanlarından Oluşan Askeri Hastanelerin, İaşelerinin İyileştirilmesi Konusunda Sıhhiye Vekâletinden Görüş Alınması Gerektiğiyle İlgili Belge

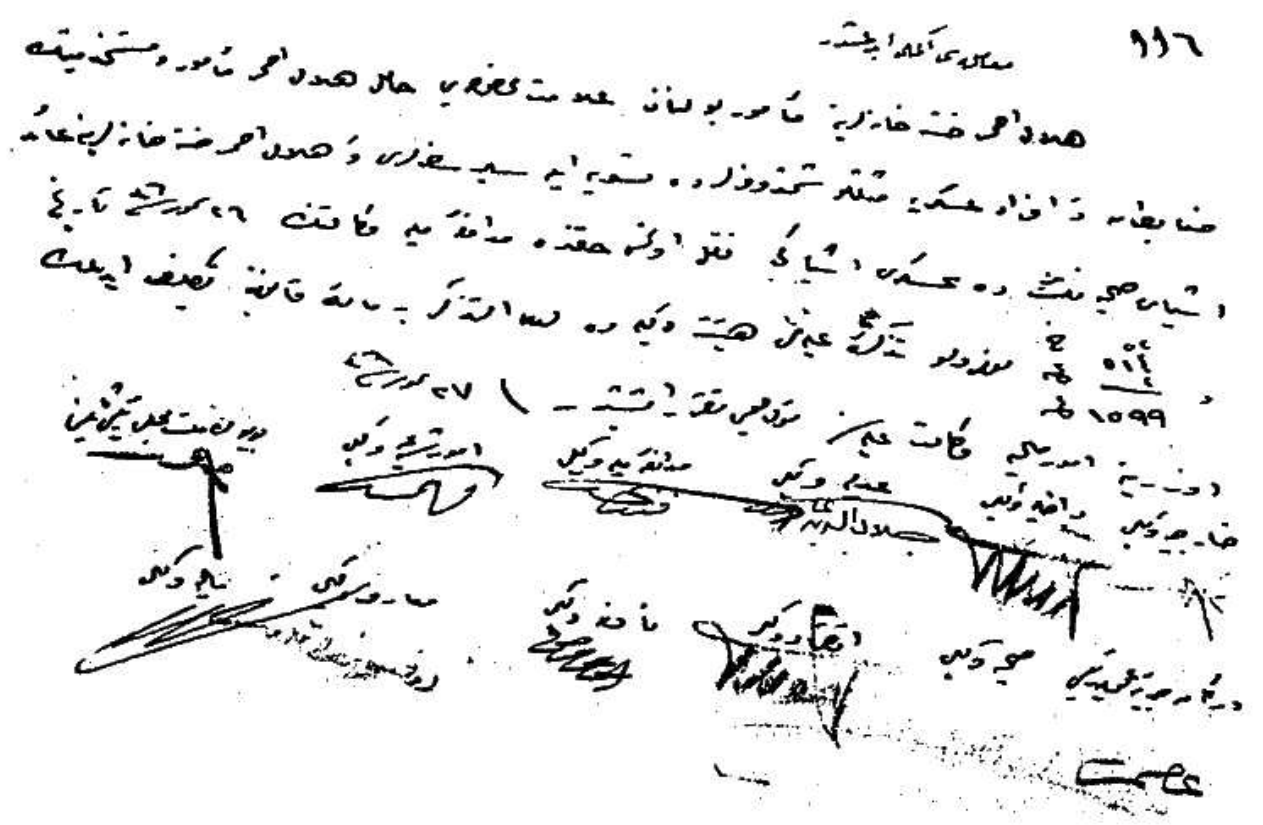

EK-2: Hilal-İ Ahmer Personelinin Tipkı Askeri Görevliler Gibi Demir Yolları Hizmetlerinden Faydalanıp Sağlık Malzemesi Taşıyabileceğini Gösterir Belge 


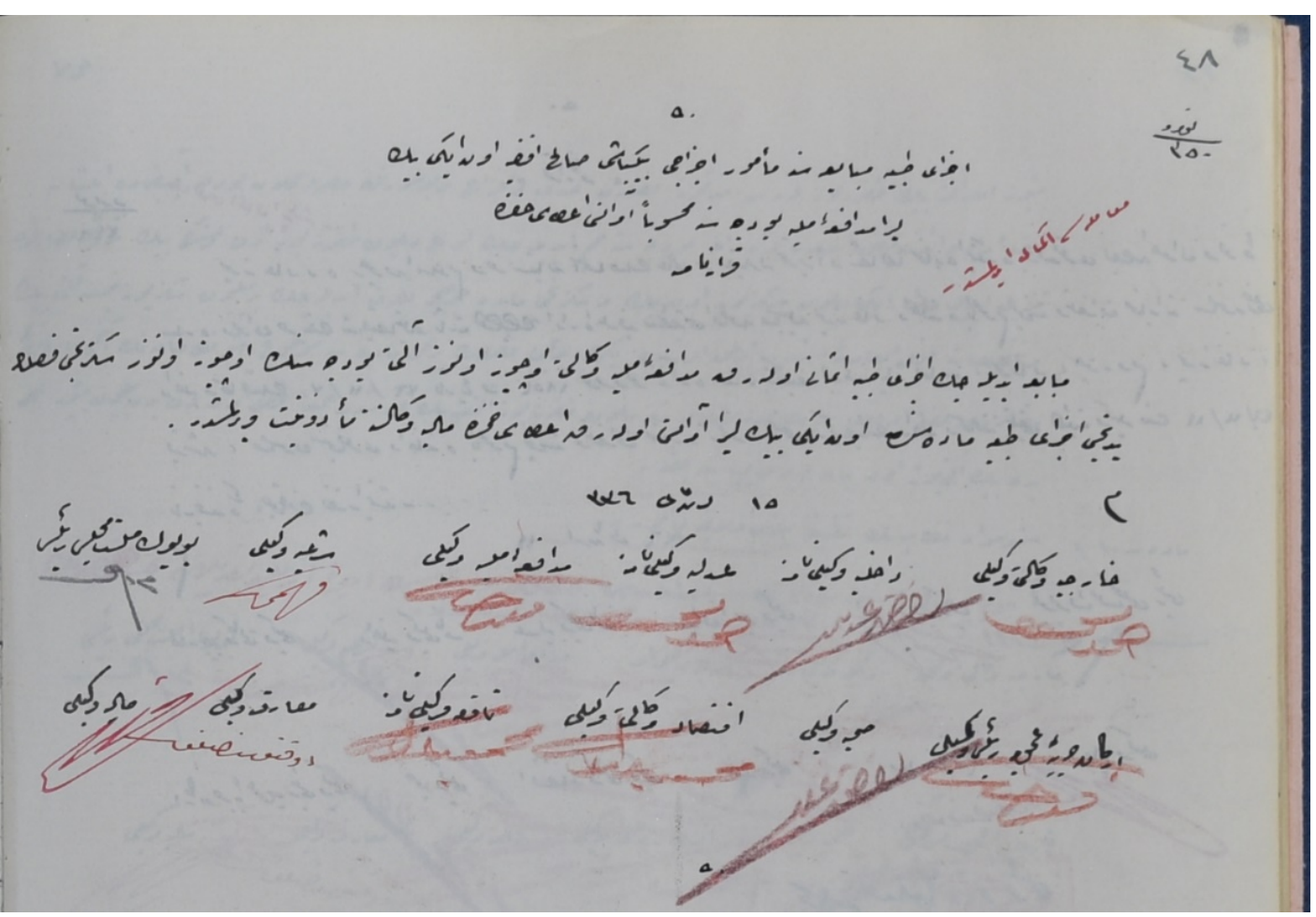

EK-3: Müdafaa-i Millîye Vekâleti Adına İlaç Alınması İçin Avans Verildiğini Gösterir Belge

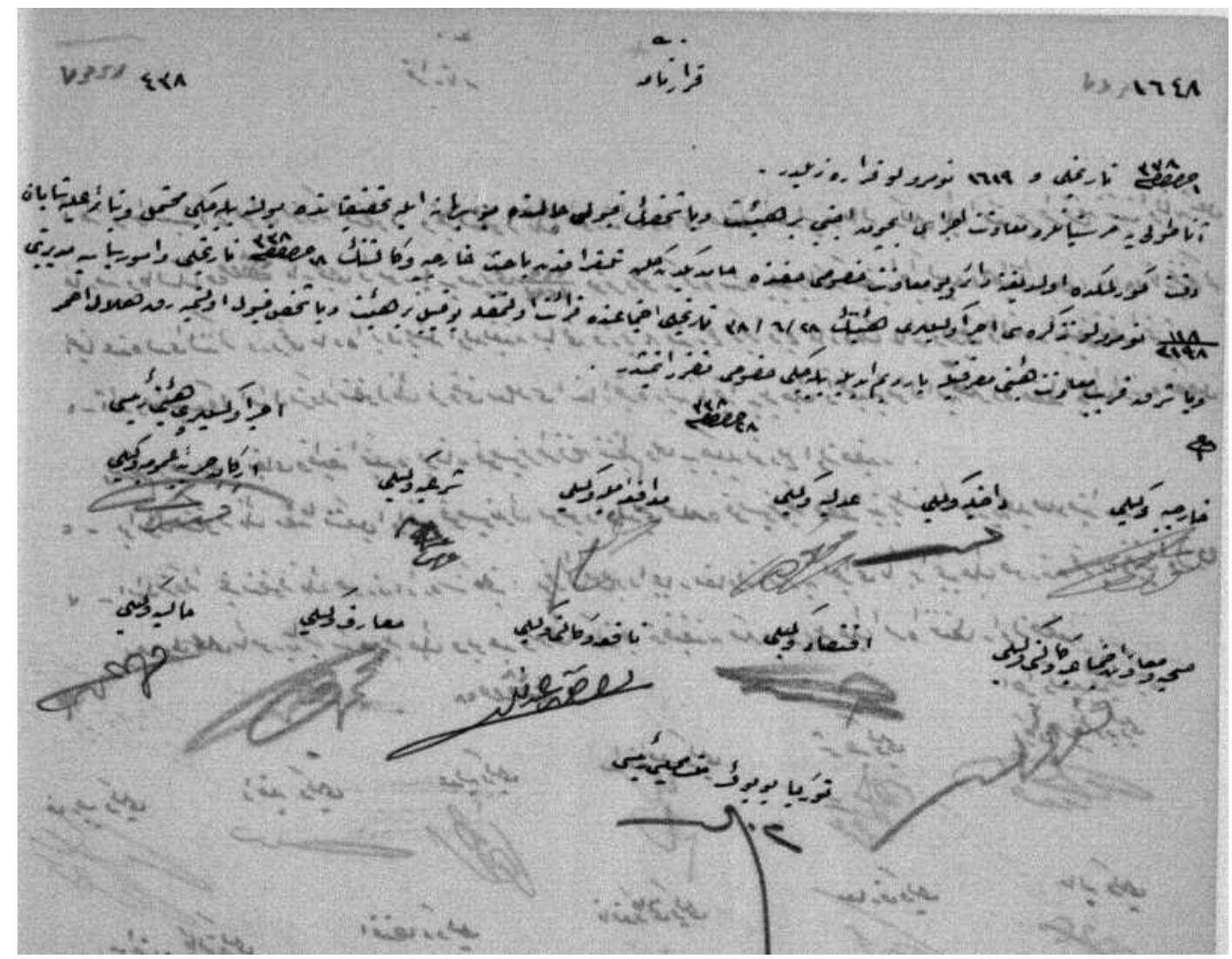

EK-4: Muhtaçlara Sadece Hilal-i Ahmer ve Şark-1 Karib Muavenet Heyetinin Yardım Yapabileceğine Dair Kararname 


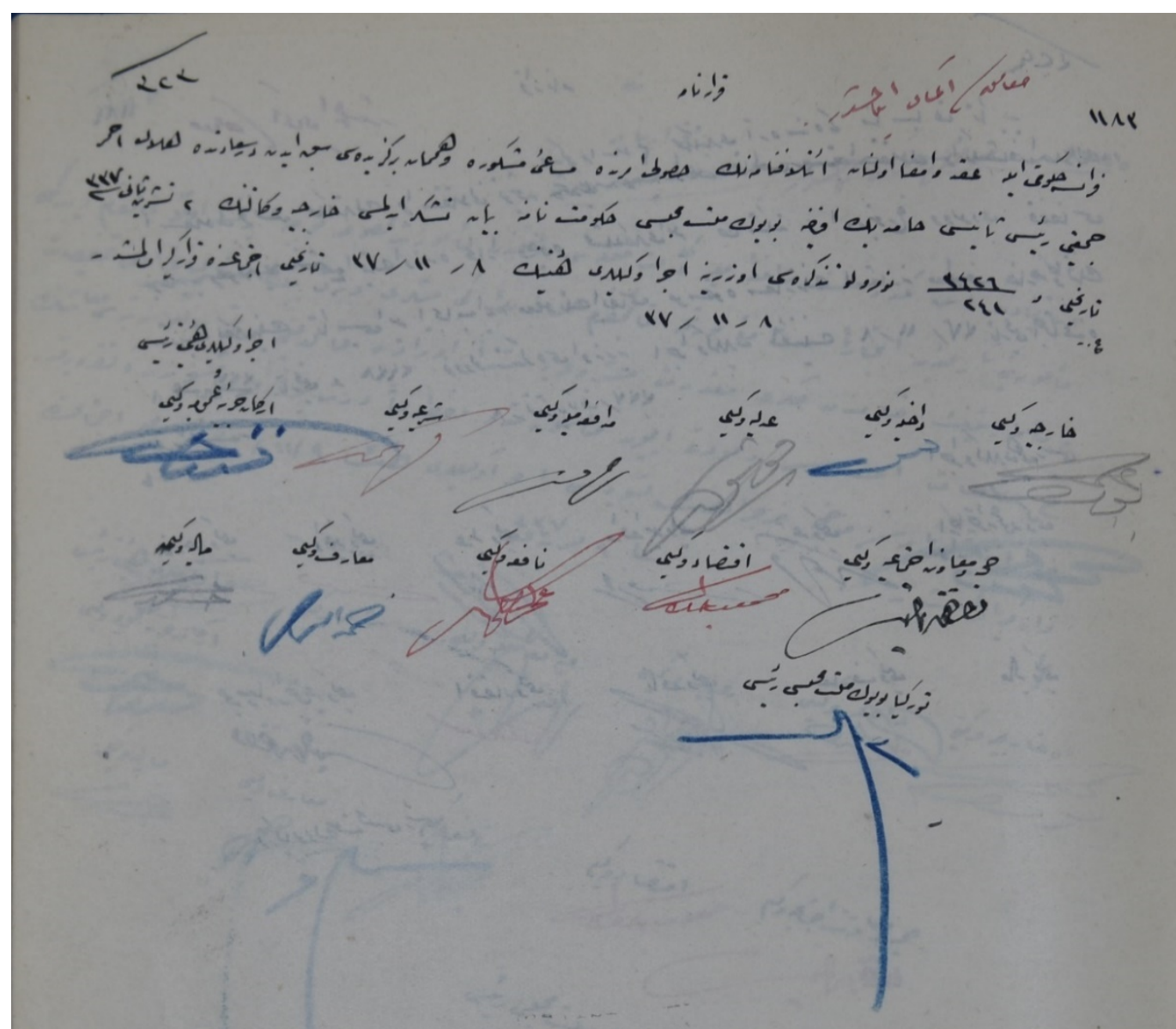

EK-5: Hilal-i Ahmer II. Başkanına TBMM Hükümetinin Teşekkür Ettiğini Gösterir Belge 


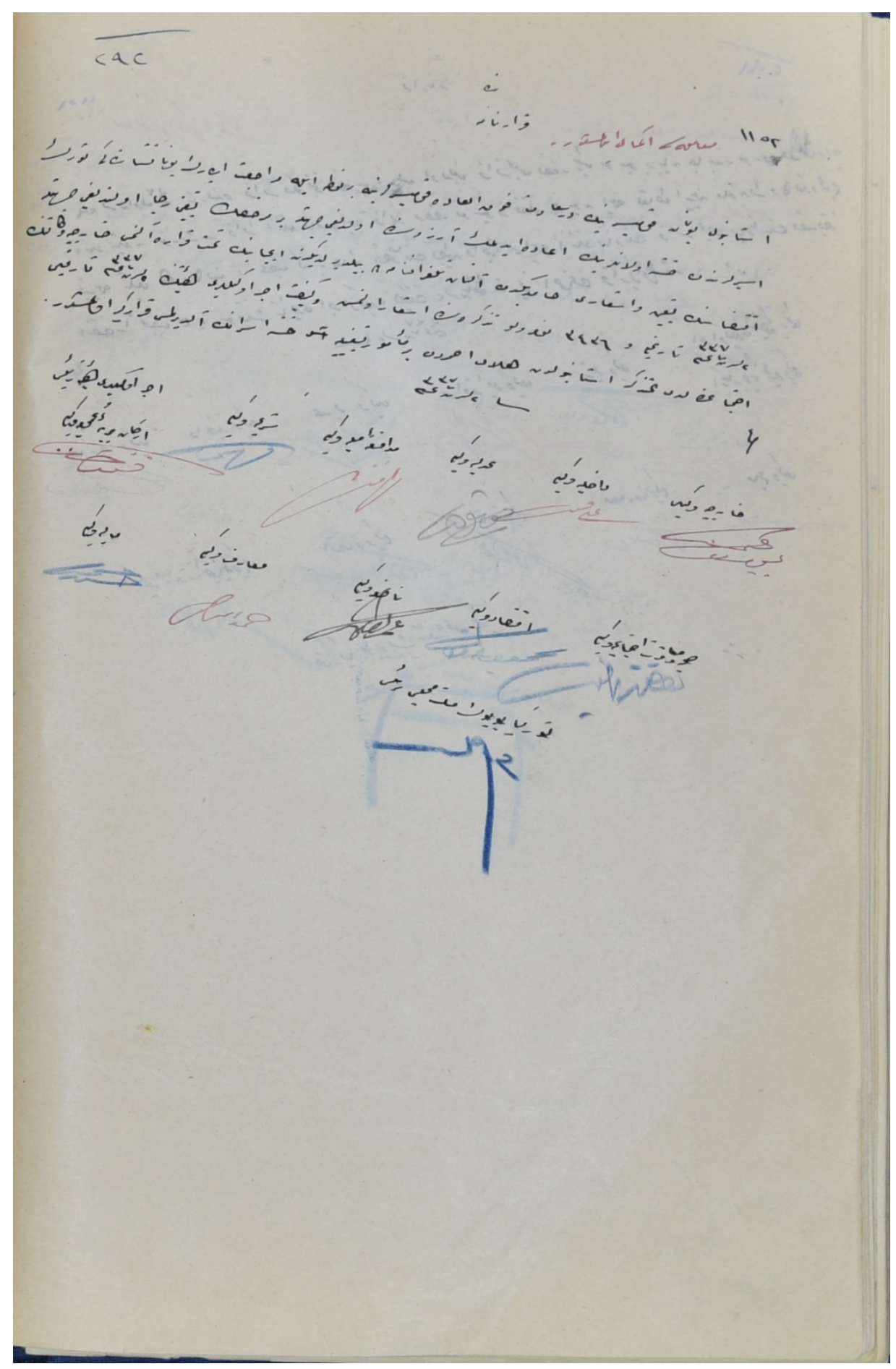

EK-6: Yunanistan'daki Hasta Esirlerimizin İadesi İçin Bir Hilal-i Ahmer Memurunun Görevlendirilmesiyle İlgili Belge 


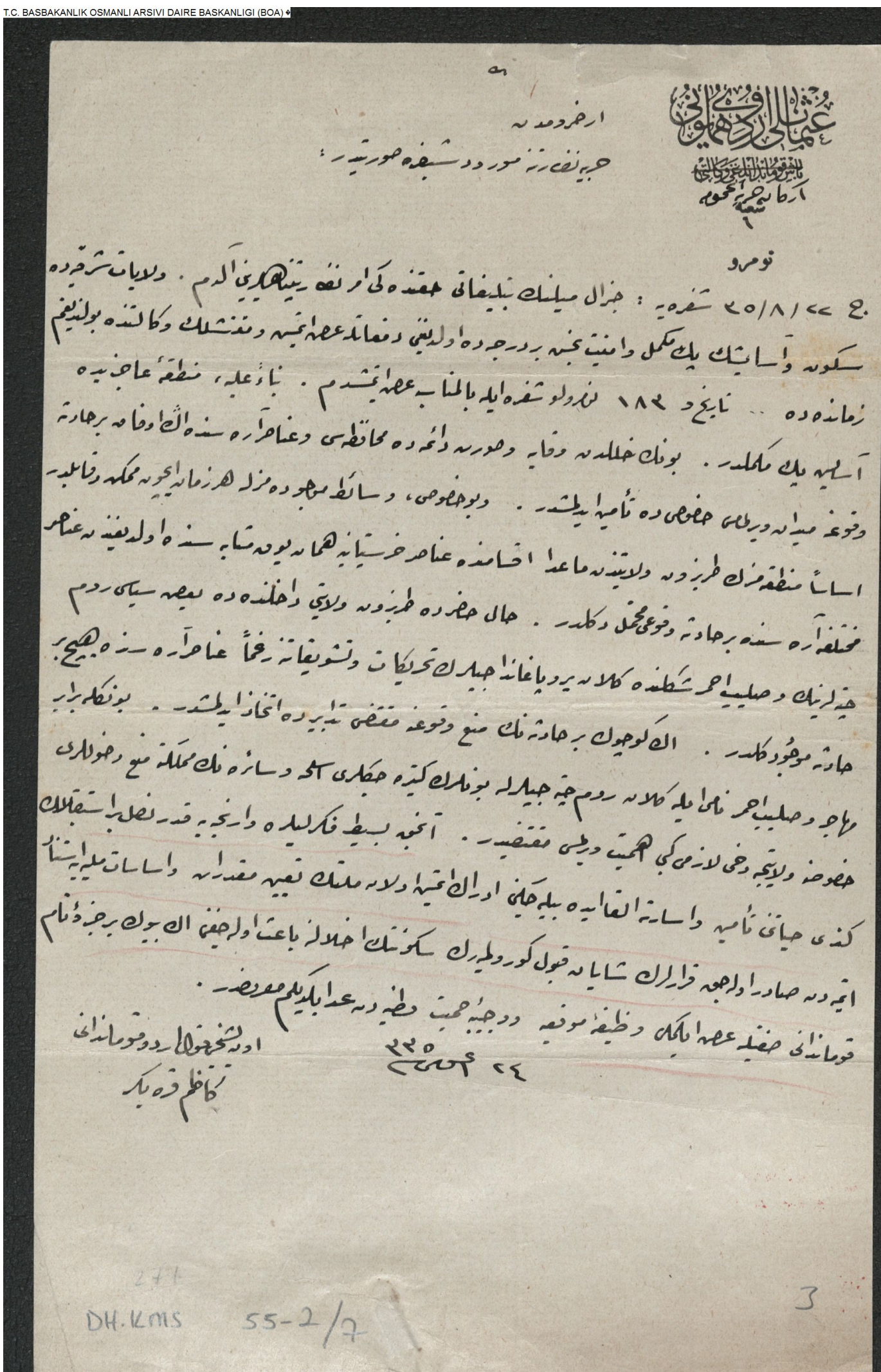

DH.KMS.00055.2.00007.003

EK-7: Kazım Karabekir'in Salib-i Ahmer ve Muhacirlerin Anadolu'ya Silah Sevkiyatı Yaptığına Dair Tespitlerini Gösterir Belge 


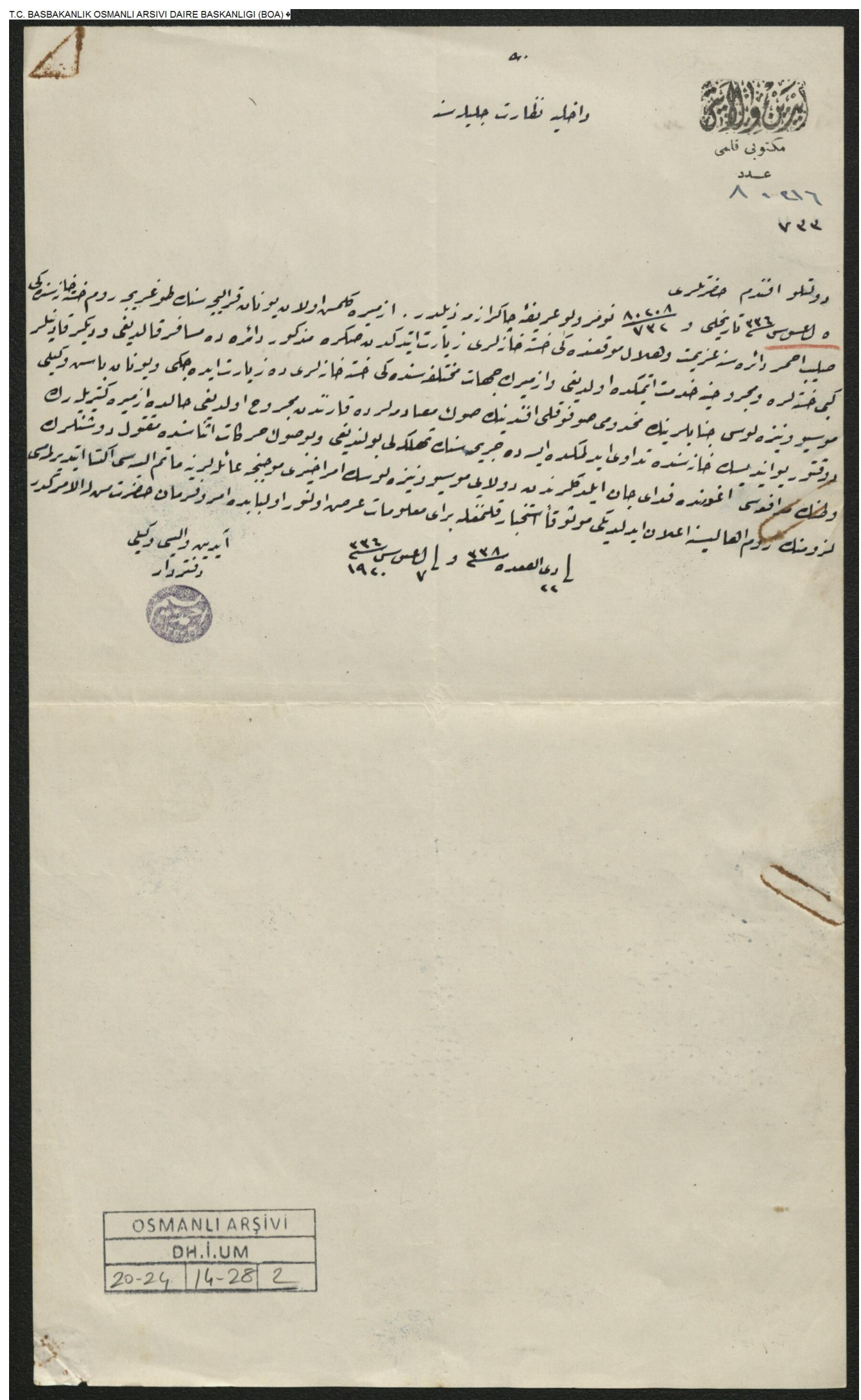

DH.İ.UM.00020.24.00014.28.002

EK-8: Yunan Kraliçesinin Salib-i Ahmer Hastanelerini Ziyaret Ettiğini Gösterir Belge 


\section{Extended Abstract}

\section{Purpose}

Within the framework of the understanding that history is the memory of societies, it is extremely important to reveal the conditions under which the National Struggle was won, in which the Turks were tested with fire. From this point of view, throughout the study, how health services were provided during the Battles of Inönü in order to contribute to the formation of a common and solid memory was revealed. In these battles, it was tried to draw attention to the actions of the Hilal-i Ahmer, who was founded in the second half of the 19th century according to the principle of "affection for the homeland, helping the wounded". The areas in which the Hilal-i Ahmer strengthened the hand of the nationalists by going beyond being a health institution was examined. Hilal-i Ahmer's dignity in sociocultural and diplomacy has been pointed out to the possibilities offered to the command committee of the war. It is detailed how the Turkish nation can coordinate around Hilal-i Ahmer even under the most difficult conditions. Despite these developments on the Turkish side, the reasons for the activities of the Greek Community of Salib-i Ahmer, which cannot be associated with any law of war, have been interpreted with an objective point of view.

\section{Design and Methodology}

In the original study, which was written to show that a war consists of various components, the traces of the developments other than the headquarters and commands in the Battles of Inönü were traced. At this point, the General Staff Military History and Strategic Studies Presidency Archive, State Archives Presidency Ottoman Archive, State Archives Presidency Republic Archive and Red Crescent Archive were used in order to reach information and comments. At first the Ottoman/Turkey Hilal-i Ahmer's Journal and Tawhid-i Efkar media organs of the period were scanned. In order to analyze the critical importance of the Battles of İnönü in the War of Independence on a more solid ground, domestic and foreign works written on the subject were carefully examined. Within the scope of national consciousness-based responsible historiography, archivebased documentary sources were also consulted in order to ensure the proper absorption of the proposed problematic.

\section{Findings}

At the end of the systematic data scanning, it was understood that Hilal-i Ahmer acted like a state in the İnönü Wars that took place at short intervals. Especially after the Greek atrocities in Western Anatolia, the hospital opened in Eskişehir had great benefits for the Turkish army. In fact, this hospital has served as a model for the health institutions to be opened in other provinces. In this way, contributions were made to the construction of the health infrastructure of the modern Republic. Hilal-i Ahmer, while treating the wounded on the one hand, on the other hand strengthened the national ties during the war by protecting the poor.

Throughout history, the Turkish nation has always managed to be a whole with its men and women. Through Hilal-i Ahmer in the Battles of İnönü, Turkish women proved how devoted they supported the national resistance. The association, which enabled the prisoners of war and Turks abroad to contact their families, helped reduce the number of disappeared. It has alleviated the economic burden of nationalists by playing an important role in collecting donations given to the TGNA not only from within the country but also across the border. With its unique institutional structure, Hilal-i Ahmer has been taken as an example by the health organizations that are trying to be established in countries such as Afghanistan. The injustices committed by the Greek Salib-i Ahmer community and Greek gangs in Anatolia were announced to the world public opinion through Hilal-i Ahmer.

\section{Research Limitations}

In the article, which deals with the events just before and after the Battles of İnönü, it is mentioned how vital health logistics is for a state no matter what century it is. However, the nature of the two communities 
mentioned in the events of this period was diametrically opposed to each other. On the one hand, there was the Turkish Hilal-i Ahmer, acting with the feelings of benevolence coming from its historical elevations, and the Greek Salib-i Ahmer community, which terrorized the environment on the other. Salib-i Ahmer, who tried to fulfill the military and political instructions given by the Greek Government, did other things than reach out to the war victims during his activity in Anatolia. This situation increased the burden of Hilal-i Ahmer, who was already struggling with great difficulties, several times more. The society, which deviated from missionary to arms smuggling, carried water to the mills of the imperialists. He even tortured the local Greeks in Anatolia and Thrace, who behaved incompatible with their interests for this sake.

\section{Implications (Theoretical, Practical and Social)}

While the Greek Community of Salib-i Ahmer transferred many Greek committee members to Anatolia, they condoned their damage to places such as schools, places of worship and hospitals that symbolize the common values of humanity. At this point, during the years of the War of Independence, the Turkish side is not only against the occupying states; It is understood that he is fighting for humanity and independence against a largescale organization with deep ties to each other. It is not possible to explain the activities of Crescent Ahmer as an ordinary health activity or social solidarity movement in the face of what the Greek Salib-i Ahmer community did. Hilal-i Ahmer taught the humanity lesson to the whole world during the Battles of İnönü, just like his present-day successor, the Red Crescent. At that time, foreign observers have arrived in Turkey to visit Hilal-i Ahmer's efforts were met with appreciation.

The research comparing the works of two prominent health communities in the Battles of Inönü, which contributed greatly to the formation of morale unity on the Turkish side during the War of Independence, will partially guide the scientists who will investigate this area in the future. Because it is not possible to say that the logistical support works of the years of national resistance are sufficient, especially when compared to the ones related to Ottoman History. In addition, more specific research is required to clearly understand which forces Mustafa Kemal Atatürk and his friends resisted along the armistice corridor.

\section{Originality/Value}

Therefore, each battle within the National Struggle as a whole has a different value. The Battles of İnönü are the conflicts in which the first disciplined organization attempts were made in Western Anatolia during the war of independence. Hilal-i Ahmer, proving that the sacrifices to be made for the spirit of Defense of the Law will not be in vain with its function in these battles, and mobilized the patriots.

Studies on historical science in the modern world are now focused on a narrower time frame and a specific region. Turkish historiography has not made enough progress in this regard yet. In this research, the differences between Hilal-i Ahmer and the Greek Salib-i Ahmet in understanding, purpose and behavior styles are taken into consideration one by one. Thus, it was stated how the Turkish and Greek sides acted during the Battles of Inönü. It has been tried to inspire new and young researchers to criticize the War of Independence with these aspects.

Araştırmacı Katkısı: Fahri ÖZTEKE(\%100). 